\title{
Towards the Constitutionalization of New Forms of Governance: A Revised Institutional Framework for the European Employment Strategy
}

\author{
Samantha Velluti*
}

\section{The Open Method of Co-ordination as a Co-regulatory Governance Paradigm for EU-level Social Policy}

\section{A. INTRODUCTION}

Recent actions and strategies by the EU institutions in the area of social policy sensu lato reveal an increase in the use of complementary ${ }^{1}$ or rather alternative methods of regulation that enhance diversity and pave the way towards what I define as a 'transverse form of policy-making'. ${ }^{2}$ This new process draws upon a trans-national multi-tiered form of governance ${ }^{3}$ and basis of self-regulation, ${ }^{4}$

\footnotetext{
* Lecturer in Law, University of Manchester. I would like to thank Erika Szyszczak for her encouragement and for her valuable comments on an earlier draft of the article. The views expressed are solely those of the author.

1 See EC Commission White Paper on EU Governance COM(2001)428, 20-2.

2 Confront this definition with the broader notions of 'flexibility' or 'differentiated integration process'. See EC Commission, 'Targeted Socio-Economic Research, I-Guidance note relating to the work programme 1996' (Office for Official Publications of the European Communities, Luxembourg, 1996) 4 and 10, where the concept of 'transversality' is used to highlight the interaction between the different elements/themes of the Fourth Framework programme (1994-8); N. Walker, 'Sovereignty and Differentiated Integration in the European Union' (1998) 4 ELJ 355-88; C.D. Ehlermann, 'Differentiation, Flexibility, Closer Co-operation: The New Provisions of the Amsterdam Treaty' (1998) 4 ELJ 246-70; F. Tuytschawer, Differentiation in European Union Law (Hart Publishing, Oxford, 1999). The different terminology does not entail a conceptual difference. Both terms in fact describe the gradual shift towards a multi-tiered system of policy-making at the European level. The difference lies in the fact that while 'transverse form of policy-making' refers specifically to the implementation of EU policies, and for the purpose of the present chap., to EU social policy, 'differentiation' describes the development of the European integration process as a whole and should be contextualized within the ongoing debate on whether the EU is a polity as such. See C. Barnard, 'Flexibility and Social Policy' in G. de Búrca and J. Scott (eds.), Constitutional Change in the EU, From Uniformity to Flexibility (Hart Publishing, Oxford, 2000), 4.

3 See I.-J. Sand, 'Understanding the New Forms of Governance: Mutually Interdependent, Reflexive, Destabilised and Competing Institutions' (1998) 4 ELJ 276-86; A. Benz and B. Eberlein, 'Regions in European Governance: The Logic of Multi-Level Interaction', Working Paper RSC No. 98/31 (online), available at: www.iue.it/ERPA/Mainfiles/../../RSC/wp-Text/98_31.html.

${ }_{4} \mathrm{COM}(2001) 428,20$, where self-regulation is referred to as one of the complementary tools to legislation.
} 
co-regulation, ${ }^{5}$ voluntary networks, and more specifically on the interaction of actors distributed across the various levels of policy-making. It is articulated upon 'co-operative and horizontal' 6 forms of subsidiarity and proximity. ${ }^{7}$ The literature concerning the study of these recent developments, both from a political science and a legal perspective, is abundant. ${ }^{8}$ According to Ladeur's autopoietic theory, ${ }^{9}$ the process is moving from a 'hierarchy of norms to the heterarchy of changing patterns of legal inter-relationships', i.e., a system where the existing bottom-to-top mobilization leads to the creation of a distributed order strictly connected to its own 'process of self-generation', and which is not based on a 'fundamental unity nor on a universal rationality'. ${ }^{10} \mathrm{In}$ the context of legal theory, Pernice describes the European Union as being a form of 'multi-level constitutionalism', i.e., 'a divided power system, in which each level of government, regional (or Länder), national (State) and supranational (European), reflects one or two or more possible political identities of the citizens concerned, i.e. different levels of society'.11 In addition, Pernice introduces the concept of 'European multi-level constitution', defining it as the sum of the constitutions of the Member States linked to one another through supranational constitutional norms of the European Treaties (Verfassungsverbund) and which 'bridges the apparent conflict between European constitutionalism and the constitutionalism of the Member States.. ${ }^{12}$ Swyngedouw, in referring to 'glocalization'-by merging the two words 'globalization' and 'local'-emphasizes how globalization is fostering the promotion of bottom-to-top processes and thus enhancing new forms of governance. ${ }^{13}$

5 'Co-regulation combines binding legislative and regulatory action within actions taken by the actors most concerned, drawing on their practical expertise': $\operatorname{COM}(2001) 428,21$, where the Commission has also outlined the conditions for its application.

${ }^{6}$ For a definition of horizontal subsidiarity see G. de Búrca, 'Reappraising Subsidiarity's Significance after Amsterdam', Jean Monnet Working Paper, No. 7/99, 6 (online), available at: www.law.harvard.edu/Programs/JeanMonnet/paers/99/990702.htm.

7 Decisions should be taken as closely as possible to the grass roots level. See C. Paterman, Participation and Democratic Theory (Cambridge University Press, Cambridge, 1970), who refers to proximity in order to develop a more democratic workplace; see also N. Bernard, 'Legitimising EU Law: Is the Social Dialogue the Way Forward? Some reflections Around the UEAPME Case' in J. Shaw (ed.), Social Law and Policy in an Evolving European Union (Hart Publishing, Oxford, 2000), 292, who defines proximity as having three meanings: according to the territorial level, it refers to decentralization or devolution of power; secondly it represents a bridge between the public and private spheres of policy-making; thirdly, it refers to the matter or subject of decisionmaking, issues that are close to the citizen's daily experience.

${ }^{8}$ For detailed analysis of governance issues see various studies available online at: http:// europa.eu.int/comm/governance/index_en.htm.

9 See K.-H. Ladeur, 'The Theory of Autopoiesis as an Approach to Better Understanding pf Post-modern Law, From the Hierarchy of Norms to the Heterarchy of Changing Patterns of Legal Inter-relationships', EUI Working Paper, Law series, No. 99/3, 6-18 available online at: www.iue.i/PUB/law_fm.html. 10 Ibid., 10-11.

11 See I. Pernice, 'Multi-level Constitutionalism and the Treaty of Amsterdam: European Constitution-Making Revised?' (1999) 36 CMLRev. 706.

12 Ibid., 307.

13 See E. Swyngedouw, 'The Mammon Quest: “Glocalisation,” Interspatial Competition and the Monetary Order: The Construction of New Scales' in M. Dunford and G. Kaflakis (eds.), Cities and Regions in the New Europe (Belhaven Press, London, 1992), 39-67. 
Finally, Rosenau refers to 'fragmigration' to describe the enmeshment of integration and fragmentation at the global level. ${ }^{14}$

The main challenge with which the European Union is confronted lies in bridging the gap between these new trans-national forms of policy-making and its democratic deficit/legitimacy crisis. ${ }^{15}$ Civil society and social partners are called to play an important part in 'shaping and delivering EU policy'16 at the national level. ${ }^{17}$ Participatory democracy and deliberative supranationalism, as opposed to representative democracy and democratic supranationalism, 'potentially address the problem of how to deal with diversity in the Community and attempts to find a modus vivendi between the various actors at all levels'. ${ }^{18}$ And yet, despite representing the link between the European Union and its citizens, problems arise about what 'organized civil society' refers to at both levels of policy-making and its boundaries with social dialogue. Secondly, the ambiguity of the concept increases the confusion surrounding the already highly complex distribution of competence in the European Union and augments the dispersion and fragmentation of the decision-making system. Thirdly, trans-national governance not only poses a threat to Member States' sovereignty but, contemporaneously, also represents a challenge for the Community method. ${ }^{19}$ Both the European Union and the Member States in fact are struggling with asserting their position of authority and legitimization in the sense that the notion of Staatrecht aptly summarizes ${ }^{20}$ and, more broadly, in controlling the destabilizing effects of globalization, which has created new social structures, technologies, and knowledge-based spheres that need to be organized systematically.

Hence, what we are witnessing is a contraposition between two opposing forces, i.e., a resilient tendency towards adaptability to these new forms of diversity and flexibility versus the maintenance of a traditional conception of law, or, to put it more succinctly, regulation versus deregulation.

14 See J. Rosenau, 'A Transformed Observer in a Transforming World' (1999) 1/2 Studia Diplomatica 5-15.

15 See C. Joeges and E. Vos, 'Structures of Transnational Governance and Their Legitimacy' in J.A. Vervaele (ed.), Compliance and Enforcement of European Community Law (Kluwer Law International, The Hague, London, Boston, 1999) 79-80. See also C. Lord, 'Legitimacy, Democracy and the EU: When Abstract Questions Become Practical Policy Problem', Policy Paper 03/00, available online at: www.one-europe.ac.uk. 16 COM(2001)428, 3.

17 On the discourse of civil society see K. Armstrong, 'Rediscovering Civil Society: The European Union and the White Paper on Governance' (2002) 8 ELJ 102-32.

18 See Joeges and Vos, above n. 15, 87; C. Joerges, 'Deliberative Supranationalism-Two Defences' (2002) 8 ELJ 138.

19 See P. Pierson and S. Leibfried, ‘The Dynamics of Social Policy Integration' in P. Pierson and S. Leibfried (eds.), European Social Policy: Between Fragmentation and Integration (The Brookings, Washington, DC, 1995). The authors refer in particular to the area of social policy and argue that Member States have created structures that they can no longer control completely and that it is these actors, together with trans-national bodies, that primarily contribute to the developments in social policy.

${ }_{20}$ According to this concept the law is adopted exclusively by the State and is at the same time at the exclusive service of the State. See O. Mayer, Deutsches Verwaltungsrecht (Duncker \& Humblot, Leipzig, 1895) $64 \mathrm{ff}$. 
This explains why the Commission's White Paper on EU Governance appears to be more concerned with limiting the sphere of action of these new processes rather than in fostering it, ${ }^{21}$ and why these new actors are, for the most part, excluded from the decision-making sphere and are given a more important role in the implementation side of policy-making. In this sense, these actors may clearly be seen as being regulatory and legitimacy resources of the European Union. Scott and Trubek aptly describe this current state of affairs by introducing a distinction between 'new/old governance' (NOG), i.e., framework directives, comitology, and civil society, which do not represent 'fully-fledged alternatives' to the Community Method and new governance', i.e., partnership, social dialogue, and the OMC, which, on the contrary, represents a departure from the Community Method. ${ }^{22}$

The above analysis highlights the Community's structural incapacity to regulate these new processes. It also reveals other important aspects of EU governance, particularly in the field of social policy. The orientation towards forms of proceduralization of standards and common values ${ }^{23}$ and the preference for management by objectives rather than management by regulation, ${ }^{24}$ in the light of the opacity and fragility of the institutional framework in which these new trans-national forms of policy-making operate, reveal the existence of a hidden agenda on the part of the Commission, which is convergence in disguise. Barnard and Deakin effectively describe the latter as a form of 'reflexive law or harmonization', i.e., regulatory interventions, which rely on the induction of 'second-order effects' rather than direct prescription, and which 'couple external regulation with self-regulatory processes.' 25

In the next section I will examine the above issues in the context of the European Employment Strategy/Open Method of Co-ordination, which illustrates writ large the issues analysed so far, following which I will consider its strengths and weaknesses (section IC).

$21 \operatorname{COM}(2001) 428,21-2$, where the Commission outlines the conditions for the application of co-regulation and the open method of co-ordination.

22 See J. Scott and D.M. Trubek, 'Mind the Gap: Law and New Approaches to Governance in the European Union' (2002) 8 ELJ 2-5; see A. Lo Faro, Regulating Social Europe, Reality and Myth of Collective Bargaining in the EC Legal Order (Hart Publishing, Oxford, 2000) 38-49. The author refers to first and second generation alternatives respectively to describe differences in EU policymaking.

23 See Barnard, above n. 2, 211.

${ }_{24}$ See M. Biagi, 'The Impact of European Employment Strategy on Role of Labour Law and Industrial Relations' [2000] International Journal of Comparative Labour Law and Industrial Relations 161.

25 See C. Barnard and S. Deakin, 'In Search of Coherence: Social Policy, the Single Market and Fundamental Rights' [2000] ILJ 341. For literature on the concept of 'reflexive law' see G. Teubner, 'Substantive and Reflexive Elements in Modern Law' (1983) 17 Law and Society Review 239; R. Rogowski and T. Wilthagen (eds.), Reflexive Labour Law (Kluwer Law International, The Hague, London, Boston, 1994); S. Deakin, 'Two Types of Regulatory Competition: Competitive Federalism versus Reflexive Harmonisation. A Law and Economics Perspective on Centros' (2000) 2 CYELS 231. 
B. THE IMPLEMENTATION OF THE EUROPEAN EMPLOYMENT

STRATEGY THROUGH THE OPEN METHOD OF CO-ORDINATION

As a new form of soft law, ${ }^{26}$ the European Employment Strategy (EES), also compared to previous non-binding legal instruments, constitutes a challenge for legal theory. ${ }^{27}$ The adoption of a common strategy for employment with the introduction of a new Title in the EC Treaty, Title VIII, was agreed at the 1997 Amsterdam Summit ${ }^{28}$ and fast-tracked by the 'Luxembourg Process'. ${ }^{29}$

The implementation of the EES is an iterative and multi-level process, which involves several steps and the adoption of various acts and measures: ${ }^{30}$

- conclusions by the Presidency of the European Council on the employment situation within the Member States;

- joint annual report (JER) by the Council and the Commission;

- guidelines (EPGs) by the Council which were based on a four-pillar structure (employability, entrepeneurship, adaptability, and equal opportunities) that has been eliminated in the new EPGs process, for simplification purposes (this is discussed in section $\mathrm{C}$ );

-National Action Plans (NAPs) by the Member States;

-recommendations by the Council, if the case so requires, to the Member States;

-incentives measures by the Council designed to encourage co-operation between Member States and to support their action in the field of employment through initiatives aimed at developing exchanges of information and best practices;

-monitoring the employment situation and policies in the Member States with the creation of an Employment Committee assigned with the task of formulating opinions on the labour market performance; assessment report on the implementation of the EPGs by the Commission (ARI).

The submission of NAPs by Member States in co-operation with the social partners, in accordance with common objectives and indicators established in the annual EPGs, and the evaluation made by the European Institutions through the JER and the ARI are illustrative of the way the 're-regulation' or 're-nationalization process' ${ }^{31}$ operates in practice. Within the Employment

${ }^{26}$ For a definition of soft law in the Community context see K.C. Wellens and G.M. Borchardt, 'Soft Law in European Community Law' (1989) 14 EL Rev. 285.

27 See E. Szyszczak, 'The Evolving European Employment Strategy' in J. Shaw (ed.), Social Law and Policy in an Evolving European Union (Hart Publishing, Oxford, 2000), 197-204 and 216-220).

28 See Presidency Conclusions of the Amsterdam European Council, 16 and 17 June 1997. All European Council Presidency Conclusions are available online at URL: http//ue.eu.int/en/Info/ eurocouncil/index.htm (accessed 8 Oct. 2001).

${ }^{29}$ See Presidency Conclusions of the Extraordinary European Council Meeting on Employment, Luxembourg, 20 and 21 Nov. 1997, 4-5, paras. 25-35. 30 See Arts. 125-130 EC.

${ }^{31}$ See S. Sciarra, 'Global or Re-nationalised? Past and Future of European Labour Law' in F. Snyder (ed.), The Europeanisation of Law: The Legal Effects of European Integration (Hart Publishing, Oxford, 2000) 270-1; C. Lafoucrière, 'The European Employment Strategy, The Third Pillar: Adaptability’, ETUI Working Paper, DWP 2000.01.03, 7. 
Strategy the EU institutions in fact have a supervision and monitoring role, assessing Member States' structural, employment, education, and health policies in accordance with the common objectives established in the EPGs. Moreover, the Council may make recommendations to certain Member States on specific employment policies. The EES therefore represents a sea change with regard to the EU law-making process both at the national and at the European level. ${ }^{32}$ It does this in two ways. First, it introduces innovation whilst maintaining intact the extant institutional design. ${ }^{33}$ Secondly, it entails a shift from 'social law and legislative initiatives, towards soft law, or rather policies aimed at employment creation, which for the most part eschew legislation' ${ }^{34}$

Furthermore, the use of more flexible non-binding legal instruments and the creation of a nexus between the different EU policy areas broaden the EES scope of action, which goes beyond the field of social policy stricto sensu. Thus, the EES aims at developing a social dimension to the activities of the European Union. ${ }^{35}$

At the Lisbon Summit followed by subsequent summits the EES and similar policy tools have been defined as regulatory instruments to be included in the 'Open Method of Co-ordination' (OMC). ${ }^{36}$

32 For a detailed account and analysis of the Employment Strategy see among others: J. Goetschy, 'The European Employment Strategy: Genesis and Development' (1999) 5 European Journal of Industrial Relations 117-37; Szyszczak, above n. 27, 197-220; M. Biagi, 'The Impact of European Employment Strategy on Role of Labour Law and Industrial Relations' [2000] International Journal of Comparative Labour Law and Industrial Relations 155-73; E. Szyszczak, 'III. Social Policy' (2001) 50 ICLQ 175-86; E. Szyszczak, 'The New Paradigm for Social Policy: A Virtuous Circle?' (2001) 38 CML Rev. 1125-70; S. Ball, 'The European Employment Strategy: The Will but not the Way?' (2001) ILJ 353-75; J. Goetschy, 'The European Employment Strategy from Amsterdam to Stockholm: Has It Reached Its Cruising Speed Yet?' in B. Towers and M. Terry (eds.), Industrial Relations Journal: European Annual Review (Blackwell, London, 2001); D.M. Trubek and J. Mosher, 'New Governance, EU Employment Policy, and the European Social Model' in Symposium: Responses to the European Commission's White Paper on Governance, sections 5 \& 6, available at: www.jeanmonnetprogram.org/papers/01/0100501.html; J. Kenner, EU Employment Law, From Rome to Amsterdam (Hart Publishing, Oxford, 2003) chap. 11.

${ }^{33}$ See F. Scharpf, 'European Governance: Common Concerns vs. The Challenge of Diversity' in Symposium: Responses to the European Commission's White Paper on Governance, above n. 32.

${ }_{34}$ See D. Ashiagbor, 'EMU and the Shift in the European Labour Law Agenda: from "Social Policy" to "Employment Policy" ' (2001) 7 ELJ 317.

35 See Presidency Conclusions of the Extraordinary European Council Meeting on Employment, Luxembourg, 20 and 21 Nov. 1997, 4-5, paras. 25-35. The major policy areas are taxation, research and innovation, trans-European transport networks, structural funds, and information society; Presidency Conclusions of the Lisbon European Council, 23 and 24 Mar. 2000, para. 5 and paras. 8-23; Presidency Conclusions of the Santa Maria Da Feira Summit, 19 and 20 June 2000, paras. 19-39; Presidency Conclusions of the Nice European Council Meeting, 7, 8, and 9 Dec. 2000, Annex I, 11-22; Presidency Conclusions of the Stockholm Summit, 23 and 24 Mar. 2001, paras. 10-24, 33-52, and Annex I, 14.

${ }^{36}$ For detailed analysis of the functioning of the Open Method of Co-ordination see, among others, J. Mosher, 'Open Method of Co-ordination: Functional and Political Origins' (2000) European Communities Studies Association Review 7 ff.; D. Hodson and I. Maher, 'The Open Method as a New Mode of Governance: The Case of Soft Economic Policy Co-ordination' (2001) 39 JCMS 719-46; C. de la Porte, 'Is the Open Method of Co-ordination Appropriate for Organising Activities at European Level in Sensitive Policy Areas?' (2002) 8 ELJ 35-58; C. de la Porte, P. Pochet, and G. Room, 'Social Benchmarking, Policy-Making and the Instruments of New Governance' (2001) 11 Journal of European Social Policy 291-307; C. Radaelli, 'Policy Transfer in the European 
The OMC has its origins in the 'hard' fiscal provisions and 'soft' economic provisions of the Economic and Monetary Union (EMU). ${ }^{37}$ With regard to the former, Articles 102a (now Article 98) to 104c (now Article 104) and 109j EC together with the Protocol on the Excessive Deficit Procedure, the Protocol on the Convergence Criteria, and the Stability and Growth Pact (SGP) ${ }^{38}$ introduced basic rules for budgetary soundness and established procedures for the surveillance of national fiscal policies. ${ }^{39}$ Member States agreed to meet certain convergence criteria in the form of benchmarks, e.g., a sound government budgetary position with budget deficits that should not exceed 3 per cent of GDP and a public debt ratio of no more than 60 per cent of GDP. ${ }^{40}$ In the event of noncompliance with the SGP, the Council could make a recommendation and issue a formal sanction in a case of infringement of the SGP. In the context of economic policy co-ordination a multilateral surveillance system was created to guarantee that national economic policies would not hinder EU economic policy objectives and, for the members of the EMU, the objectives of monetary policy. In this case, the Broad Economic Policy Guidelines (BEPGs) set up a framework for the 'soft' co-ordination of economic policies, setting out the main objectives and substituting the strict requirements of the 'hard' monetary policy provisions with peer pressure. ${ }^{41}$ The priority areas in the framework of the Lisbon Strategy are, added to employment, social protection, social security, and education. A Social Inclusion Strategy was adopted in December 2000 by the Nice European Council and a Social Protection Strategy was agreed at the Stockholm European Council. ${ }^{42}$ Moreover, it was agreed to adopt a fully decentralized approach in line with the principle of subsidiarity, in which the European Union, the Member States, the regional and local authorities, as well as social partners and civil society, would be actively involved, using variable forms of partnership. ${ }^{43}$

Union' [2000] Governance 25-43; K. Sisson and P. Marginson, 'Benchmarking and the "Europeanisation" of Social and Employment Policy', Briefing Note 3/01, in the framework of ESRC One Europe or Several?, Apr. 2001; C. de la Porte and P. Pochet (eds.), Building Social Europe through the Open Method of Co-ordination (P.I.E.-Peter Lang, Brussels, 2002); F. Bertozzi and G. Bonoli, 'Europeanisation and the Convergence of National Social and Employment Policies. What Can the Open Method of Co-ordination Achieve?', paper prepared for the 'Europeanisation of National Political Institutions' workshop, ECPR, Joint Session, Turin, 22-27 Mar. 2002.

37 See C. de la Porte, 'Is the Open Method of Co-ordination Appropriate for Organising Activities at European Level in Sensitive Policy Areas?' (2002) 8 ELJ 40-1. See also C. de la Porte and P. Pochet, 'Supple Co-ordination at EU Level and Key Actors' Involvement' in de la Porte and Pochet (eds.), above n. 36, 32-4.

38 See Resolution of the European Council on the Stability and Growth Pact, Amsterdam European Council, 16-17 June 1997 [1997] OJ C236/1.

39 See Council Regulation (EC) 1466/97 on the strengthening of the surveillance of budgetary positions and the surveillance and co-ordination of economic policies, [1997] OJ L209/1; Council Regulation (EC) 1467/97 on speeding up and clarifying the excessive deficit procedure [1997] OJ L209/6.

40 See Art. 2 of the Protocol on the Convergence Criteria Referred to in Art. 109 of the Treaty Establishing the European Community. 41 See Art. 99 EC.

42 See Presidency Conclusions of the Lisbon European Council, 23 and 24 Mar. 2000, paras. 24-34; Presidency Conclusions of the Nice European Council, 7, 8, and 9 Dec. 2000, para. 20; Presidency Conclusions of the Stockholm European Council, 23 and 24 Mar. 2001.

43 See Presidency Conclusions of the Lisbon European Council, 23 and 24 Mar. 2000, para. 38. 
Following the Lisbon Summit various institutional reforms particularly relevant to social policy sensu lato were made regarding: the Committee of the Regions, the Economic and Social Committee (ESC), and the Social Protection Committee. The Committee of the Regions has been given a more pro-active role in examining policy through the preparation of exploratory reports in advance of Commission proposals, in organizing the exchange of best practice at the local and regional levels and in reviewing the local and regional impact of certain directives, reporting to the Commission by the end of 2002 on the possibilities for more flexible means of application. ${ }^{44}$ The ESC has been assigned an important role in developing a new relationship between institutions and civil society. Like the Committee of the Regions, the ECS is to be more active in developing opinions and exploratory reports in order to help shape policies at a much earlier stage than at present. ${ }^{45}$ Finally, the Social Protection Committee's advisory status has been strengthened in order to monitor and promote co-operation and the exchange of best practices in the field of social protection. ${ }^{46}$

The two key institutional players of the OMC are the European Council and the Commission respectively. The former has a pre-eminent and co-ordinating role' to 'ensure overall coherence and effective monitoring of progress towards the new strategic goal'. ${ }^{47}$ The latter instead plays an important pro-active and methodological role, in that it shapes and defines the development and implementation of the strategy by structuring the behaviour of the various actors involved, channelling conflicts, and fostering consensus building. ${ }^{48}$

The OMC is an example of negative integration ${ }^{49}$ and provides a pragmatic rather than a principled answer to the legitimacy crisis of the European Union. ${ }^{50}$ In fact an established and embedded social policy process has gradually been taking place at the European level, ${ }^{51}$ which raises new and special problems that demand special policy initiatives and new priorities. The EES has been designed to meet these new problems. The OMC can be described as constituting an enmeshment of open participation in the implementation of policies, consensus building, exchange of best practices and information,

\footnotetext{
44 See Art. 2(42) of the Treaty of Nice, Doc. No. SN 1247/01, which amended Art. 263 EC; $\operatorname{COM}(2001) 428,14$.

45 See Art. 2(39) of the Nice Treaty, Doc. No. SN 1247/01, which has amended Art. 257 EC; $\operatorname{COM}(2001) 428,15$.

46 See Art. 2(11) of the Nice Treaty, Doc. No. SN 1247/01, 34, which has amended Art. 144 EC.

47 See 'Main Conclusions of the Lisbon Summit by the Portuguese Presidency of the EU' 1 available online at: www.portugal.ue-2000.pt/uk/news/execute/news.asp?id=1533.

48 See J. Goetschy, 'The European Employment Strategy: Genesis and Development' (1999) 5 European Journal of Industrial Relations 135.

49 See F. Scharpf, Governing in Europe: Effective and Democratic? (OUP, Oxford, 1999), chap. 2.

50 See E. Szyszczak, 'Social Policy in the Post-Nice Era' in A. Arnull and D. Wincott (eds.), Accountability and Legitimacy in the European Union (OUP, Oxford, 2002).

${ }_{51}$ See R. Nielsen and E. Szyszczak, The Social Dimension of the EU (Handelshøjskolens Forlag, Copenhagen, 1997). The authors identify this new phase as a distinctive sixth phase in the evolution of EU social policy.
} 
use of benchmarking, and, more broadly, co-operation and co-ordination within a multi-tiered framework of governance. ${ }^{52}$

Moreover, the EES/OMC is based on peer pressure. The constraint on Member States, therefore, is not legal in nature since this new mode of governance lacks any system of sanctions and enforcement procedures; it is a moral constraint or, better said, it is political. This is why these alternative regulatory methods are defined as 'soft law' as opposed to 'hard law'.53

Hence, the rigid traditional procedures have been replaced by the 'soft approach', in which the Luxembourg (employment), Cardiff (economic reform), and Cologne (macro-economic reform) processes have become increasingly co-ordinated. A High Level Forum in fact was held in Brussels on 15 June 2000, which brought together the social partners, the Union's institutions, the European Central Bank (ECB), and the European Investment Bank (EIB) to assess the co-ordinated implementation of the Luxembourg, Cardiff, and Cologne processes. ${ }^{54}$ At the Lisbon Summit it was also agreed to hold an annual European Council meeting every spring aimed at monitoring the implementation of the overall strategy agreed in Lisbon. More precisely, these special meetings are to be devoted to the examination of economic and social matters on the basis of the synthesis report prepared by the Commission and relevant reports from the Council. The first meeting was held on 23 and 24 March 2001, in Stockholm. ${ }^{55}$ Furthermore, at the Laeken Summit, the Council welcomed the decision to create and institutionalize a European Social Affairs Summit to be held before each Spring European Council Summit. ${ }^{56}$ The first one was held in Brussels on the eve of the Laeken Summit, where representatives of management and labour, members of the Presidency of the European Union, of the European Commission, and more generally of the European Council met in order to discuss issues regarding social and economic policies in the European Union. ${ }^{57}$

The next section looks at the objectives of the Employment Strategy and shows how the latter represents only a partial answer to the difficult achievement of overcoming the EU democratic deficit and legitimacy crisis.

52 See J. Scott and D.M. Trubek, 'Mind the Gap: Law and New Approaches to Governance in the European Union' (2002) 8 ELJ 6-8. The authors identify and describe succinctly 6 factors, which have fostered the increase in the use of 'new governance' instruments.

53 See W. Kenneth Abbott and D. Snidal, 'Hard and Soft Law in International Governance' (2000) 54 Int. Org. 421-56.

54 See Presidency Conclusions of the Lisbon European Council, 23 and 24 Mar. 2000, para. 40; Presidency Conclusions of the Santa Maria Da Feira Summit, 19 and 20 June 2000, paras. 19-39.

55 See Presidency Conclusions of the Lisbon European Council, 23 and 24 Mar. 2000, Employment, Economic Reform and Social Cohesion, A Strategic Goal for the Next Decade, The New Challenge, para. 7. See also Presidency Conclusions of the Santa Maria Da Feira Summit, 19 and 20 June 2000, para. 39; Presidency Conclusions of the Nice European Council Meeting, 7, 8, and 9 Dec. 2000, para. 34 .

56 See Presidency Conclusions of the European Council, Laeken, 14 and 15 Dec. 2001, 7, para. 23.

57 See D. Spinant, "European Social Summit Ahead of Laeken" and 'Social Partners to be Consulted Ahead of Summits', available at URL: http://euobserver.com/front_print.phtml? article_id $=4555$. 
It maintains that the malaise of the strategy is a direct consequence of its inherent contradiction, in that its strengths constitute, at the same time, its weaknesses.

C. THE EUROPEAN EMPLOYMENT STRATEGY:

EXPERIMENTING DELIBERATIVE SUPRANATIONALISM

The EES aims at achieving six major objectives regarding both the European and the national level of policy-making: ${ }^{58}$

(i) legitimacy of Community action;

(ii) promotion of policy learning;

(iii) efficiency of policy-making at the European and national levels;

(iv) increase of policy co-ordination among all levels of government;

(v) promotion of greater interaction between different policy areas;

(vi) promotion of trans-national forms of governance whilst maintaining a certain degree of convergence.

The first objective, legitimacy, has always been pursued by the EC institutions in the difficult achievement of promoting further integration in policy areas, which have traditionally been considered as pertaining to the national domain.

From this perspective the EES does not represent an entirely new mode of governance. Rather it may be defined as constituting a tertium genus, in that it presents elements of continuity with previous methods of policy-making in the field of social law and contemporaneously representing an innovative and qualitative break from the past.

The difficult task of promoting further convergence whilst respecting the diversity of the various labour market and industrial relations systems (objective (vi) ) was already undertaken with the Agreement on Social Policy annexed to the Maastricht Treaty (ASP). The aim of the latter was to introduce a multitiered level of policy and decision-making at the Community level, complementing the use of different regulatory tools, such as directives and non-binding legal instruments, and to co-ordinate these new methods of regulation with the Member States' different modes of legislation and/or policies. ${ }^{59}$ The result was the power assigned to the social partners to negotiate European framework agreements, which could become European law, the formal consultation of the social partners in the drafting of social policy directives, and finally the possibility of implementing directives by way of national collective agreements rather than legislation.

\footnotetext{
58 See D.M. Trubek and J. Mosher, 'New Governance, EU Employment Policy, and the European Social Model' in Symposium: Responses to the European Commission's White Paper on Governance, above n. 32, sections 5 and 6. See also J. Goetschy, 'The European Employment Strategy, Multi-level Governance and Policy Co-ordination: Past, Present and Future' in J. Zeitlin and D.M. Trubek (eds.), Governing Work and Welfare in A New Economy: European and American Experiments (OUP, Oxford, 2003).

59 In most Member States, such as France, Spain, Germany, and Italy, social issues were also or mostly dealt through non-legislative regulatory tools such as collective agreements.
} 
The Treaty of Amsterdam added further impetus to differentiation and subsidiarity with the adoption of a common strategy for employment and with a European collective bargaining system formalized in Title XI. ${ }^{60}$

These reforms were expected to increase the legitimacy of Community action in the social policy area by adding further importance to the interests of civil society and, secondly, by increasing the participation of Member States in the modernization of the European Social Model. ${ }^{61}$ Within the EES the objective is to integrate Member States' policies with the EPGs in a mediumand long-term perspective, with results which are to increase at the end of every cycle and which transcend short-term policies and can therefore more effectively solve the unemployment problem across Europe. ${ }^{62}$ Goetschy posits that "the EES is a way to "depoliticize" the unemployment problem from its immediate national contingencies and to address it in a longer-term perspective'. ${ }^{63}$ The very existence of the EES, with its EPGs and its NAPs, shows that efforts are being made to integrate the various levels of governance both at the European and national levels, strengthening the co-ordination of national and European social policies and ultimately increasing the efficiency of social regulation (objectives (iii) and (iv)).

The EES in fact has several cardinal features:

(a) most of the policies must be carried out at the national or local level. There is relatively little direct action by the EC institutions and bodies, the only exception being the (modest) use of the European structural funds to support the implementation of the EES;

(b) the primary role of the EU institutions is to provide a general framework for the strategy, to develop specific guidelines, establish a monitoring system, and finally to make annual recommendations to the Member States, where necessary;

(c) the institutional and legislative reforms are established and implemented at the national or local level.

The EES has also brought a change in the objectives of the EU agenda. Previous EU social policy and legislation were in fact oriented to labourmarket policies linked to the completion of the internal market and to the creation of EMU, without taking into account core issues of national social

60 Arts. 136-140 EC. See G. Arrigo, Il Diritto del Lavoro dell'Unione Europea, Tomo I, PrincipiFonti-Libera Circolazione e Sicurezza Sociale dei Lavoratori (Giuffrè Editore, Milan, 1998) 175-88. The author elaborates on the concept of 'double subsidiarity' in referring to the provisions of Title XI in order to emphasize the coexistence of vertical subsidiarity, i.e., the institutional dialogue between the Community and the Member States and horizontal subsidiarity, i.e., the European Social Dialogue in which management and labour co-operate with one another in stipulating collective agreements, which may then be transposed into EU law.

${ }_{61}$ See Presidency Conclusions of the Nice European Council, 7, 8, and 9 Dec. 2001, Annex I, para. 11, for a definition of European Social Model, and Communication from the Commission to the Council, the European Parliament, the Economic and Social Committee, and the Committee of the Regions, 'Social Policy Agenda', COM(2000)379 final, for the meaning of modernization of the European Social Model.

62 Goetschy, above n. 58.

63 See J. Goetschy, 'The European Employment Strategy: Genesis and Development' (1999) 5 European Journal of Industrial Relations 132. 
policies. On the contrary, the EES aims at addressing issues which directly affect national employment policies and industrial relations systems. This is explained by the fact that 'the more nationally sensitive a subject and the more difficult to resolve at national level, the more likely are Member States to become involved in an EU co-ordination procedure'. ${ }^{64}$ Syrpis maintains that 'in performance legitimacy terms, the focus has shifted away from the completion of the internal market, towards the re-distributive implications of European integration'. ${ }^{65}$ Another feature of the EES is that it integrates separate policy domains ${ }^{66}$ (objective (v) ). This can be seen in the selection of the areas on which the EPGs are adopted. ${ }^{67}$ Both the EPGs and the NAPs illustrate that the EES has already identified a series of areas where the independent operation of the various actors involved and policy boundaries are to be substituted by strict co-operation, co-ordination, and with the implementation of horizontal, preventive, and active measures and initiatives at all levels.

Moreover, even in areas that are covered by the EPGs the EES does not always demand convergence: many of the guidelines leave the States with a substantial level of discretion with regard to the ways of adopting the measures concerned. It may be argued therefore that the EES does aim at achieving convergence, but it is mostly convergence of results rather than policies. In this regard, the EES presents the same intrinsic logic of a directive. In fact, although directives are part of EC secondary 'hard' law they are binding only 'as to the result to be achieved, upon each Member State to which it is addressed, leaving to the national authorities the choice of form and methods'. ${ }^{68}$ The difference between the two regulatory methods lies in the fact that whereas the EES is a deliberative form of governance, directives are, on the contrary, based on a diplomatic operational mode. ${ }^{69}$ Secondly, as a soft law instrument, the EES does not provide any kind of legal sanction in the event of a Member State failing to meet the EPGs' objectives. This can be partially explained by the fact that in most cases the EPGs do not provide quantified targets. It would thus be hard to establish whether a Member State, given its economic and social structure, has achieved the objectives established by the EPGs. Even in cases where the target to be achieved has to correspond to the average of the three best performing Member States, ${ }^{70}$ it would be considered

${ }^{64}$ See J. Goetschy, 'The European Employment Strategy: Genesis and Development' (1999) 5 European Journal of Industrial Relations 133.

65 See P. Syrpis, 'Legitimising European Governance: Taking Subsidiarity Seriously within the Open Method of Co-ordination', EUI Working Paper, Law 2002/10.

66 See S. Ball, 'The European Employment Strategy: The Will but not the Way?' (2001) 30 ILJ 359-66; P. Syrpis, 'Smoke Without Fire: The Social Policy Agenda and the Internal Market' (2001) 30 ILJ 271-88. Both authors analyse effectively the tensions between the Employment Strategy and other EU policies.

67 Previously, measures aimed at fostering entrepreneurship, at promoting vocational (re-)training of workers, and at strengthening gender mainstreaming were not only dealt with by different authorities, institutions, and bodies but were also regulated separately.

68 See Art. 249(3) EC.

69 Contra, Goetschy, above n. 63. The author argues in fact that in the case of directives the diplomatic mode of interaction prevails, and there is a lack of deliberative process, which on the contrary typifies the EES.

70 This is the case, e.g., of G 2, regarding the Employability Pillar. 
to be politically incorrect for the Commission and the Council to impose legal sanctions on those Member States which fail to achieve quantified targets, since the industrial relations systems and the labour markets of the countries are extremely varied. This explains why the use of recommendations and the adoption of incentive measures by the Council, designed to encourage co-operation between Member States and to support their action in the field of employment through initiatives aimed at developing exchanges of information and best practices, appear far more successful in promoting structural reforms in the Member States.

Another objective of the EES is the promotion of policy learning. Teague argues that alternative regulatory and deliberative methods, which promote policy learning and innovation, are preferable to the more traditional modes of governance. ${ }^{71}$ Some scholars argue that this is an area where the EES has been most successful. ${ }^{72}$

The amendments introduced in the EPGs, in particular in the guidelines for $2001,{ }^{73}$ are evidence of the fact that overall the EES is fostering policy learning and innovation. While some are an attempt to refine the previous EPGs, the most recent guidelines introduce new objectives and targets. ${ }^{74}$ Some of the changes inserted in the EPGs exemplify the fact that the learning process is gradually affecting policy development, and the preliminary results achieved so far suggest that more changes will be made also at the national level in the years to come. ${ }^{75}$

The Dolowitz and Marsh model develops a framework for analysing the process of policy transfer. ${ }^{76}$ The model conceives policy transfer as a dependent

71 See P. Teague, 'Deliberative Governance and EU Social Policy’ (2001) 7 European Journal of Industrial Relations 7; M. Easterby Smith, M. Crossan, and D. Nicolini, 'Organisational Learning: Debates Past, Present and Future' (2000) 98 CLR 267-473.

72 See M. Ferrera, A. Hemerijk, and M. Rhodes, The Future of Social Europe: Recasting Work and Welfare in the New Economy (OUP, Oxford, 2001); Trubek and Mosher, above n. 32.

735 so-called 'horizontal objectives' have been introduced. For a detailed analysis see C. Degryse and P. Pochet, Social Developments in the European Union, Second Annual Report (OSE and ETUI, Brussels, 2001) 16-19 (online), available at: www.ose.be/en/default.htm.

${ }^{74}$ Examples of these changes are the addition of an obligation to modernize Member States' public employment services and apprenticeship systems with an effort to change the measures from passive to more preventive and active ones. Other changes concern the new obligations to eliminate the levels of poverty by reforming tax and social benefit systems; improving skill qualifications, providing training for future entrepreneurs, introducing policies to keep older workers in the workforce, and finally adopting new labour-market policies to create a European knowledge-based society. See Council Decision on guidelines for Member States' employment policies for the year 2001 of 19 Jan. 2001 [2001] OJ L22/18, G 1 and 10 (public services) and G 4, G 9, G 3, G 5 .

${ }^{75}$ See Commission Staff Working Paper, Assessment of the Implementation of the 2001 Employment Guidelines, Supporting Document to the Joint Employment Report 2001, SEC(2001) 1398; see also European Commission, Employment in Europe 2001, Recent Trends and Prospects, (online), available at: //europa.eu.int/comm/employment_social/empl\&esf/docs/empleurope 2001_en.pdf.

${ }^{76}$ See D. Dolowitz and D. Marsh, 'Learning from Abroad: The Role of Policy Transfer in Contemporary Policy-Making' (2000) 13 Governance 5. The model is built around 6 questions: (1) Why do actors engage in policy transfer?; (2) Who are the key actors involved in the policy transfer process?; (3) What is transferred?; (4) From where are lessons drawn?; (5) What are the different degrees of transfer?; (6) What restricts or facilitates the policy transfer process? 
variable and looks either at the main elements of policy transfer or at the reasons for learning. The model shows that policy transfer may also be treated as an explanatory variable, but it cannot alone be the only variable explaining policy development. This is because there is not enough evidence to confirm that policy transfer has been successful in promoting policy diffusion.

The implementation of the EES exemplifies the way the 're-nationalization process' 77 operates in practice, which, therefore, entails, on the one hand, the Europeanization of social policy and, on the other hand, increases the importance of national social pacts. ${ }^{78}$ The EES in fact promotes the creation of new employment and labour-market paradigms through the exchange of best practices and benchmarking and by linking various areas of social policy together, from both a supply- and demand-side perspective. ${ }^{79}$

Recent case studies, which assessed the implementation of the EES at the national level, however, reveal a less optimistic picture of the EES. The case studies conducted have been confronted first of all with research methodological problems. Reliable data sources are scarce and not uniform, and the availability of information varies between countries. In particular, information on Southern Mediterranean countries has been insufficiently detailed, and the NAPs are a mere reformulation of national programmes. Added to this, the difficulty also consisted in assessing the data available, i.e., crosscountry comparisons have been hard to make owing to the different national labour market patterns.

As regards the causal link between the EES and the national employment and labour-market policies the case studies have shown that the EPGs and national social policies either aimed at achieving similar objectives or, on the contrary, had different targets. In the former case, empirical studies had to assess whether there was any influence of the Strategy on the adoption of national policy objectives and, secondly, if any influence was found to have taken place, the extent of reciprocal influence of both levels of governance, i.e., whether the input was supranational or national, and, more precisely, establish whether it was the supranational or the intergovernmental element to prevail in the Strategy. In the event of different policy objectives, the research aimed at analysing national labour markets in order to explain why there was a divergence of policy objectives. The second step was to assess the effective implementation of the Strategy at the national level. In the case of non-convergence of policy objectives the research studies were conducted in order to provide some valuable proposals for reform in line with the EPGs. The countries selected for the case studies were France, Sweden, Denmark, and

77 See Sciarra, above n. 31, 270-1; Lafoucrière, above n. 31, 7.

78 See J. Goetschy, 'The European Union and National Social Pacts: Employment and Social Protection Put to the Test of Joint Regulation' in G. Fajertag and P. Pochet (eds.), Social Pacts in Europe-New Dynamics (OSE, ETUI, Brussels, 2000), 55.

79 See W. Heidemann, 'Lifelong Learning: Current Developments within Social Dialogue in Selected European Countries, An Overview', paper presented at the ETUC Conference on 'Lifelong learning', Valencia, 15-16 Feb. 2002. 
Spain, each representing different labour markets' performances and political practices. ${ }^{80}$

The case studies showed that the level of 'policy distance' between a given national context and the European objectives determines the level of European influence on the national level. ${ }^{81}$ The studies also revealed an interesting scenario. In the first place, even where the implementation of the EPGs appears to be mostly influential, i.e., in Sweden and Denmark, research revealed that the NAPs process had little direct relation with decisions made within the domestic labour-market policy process, and the apparent success of the EES was mainly due to similar objectives. Moreover, the whole process was mostly administered at the ministerial level, i.e., Ministry of Economy and Finance and Social Affairs. ${ }^{82}$ In fact even though the participation of social partners in these two countries is higher compared with that of other countries, the case studies revealed that their involvement is still more formalistic and passive-'more a matter of information than real consultation or negotiation with the government'-than at the domestic level of policymaking. ${ }^{83}$ In France research showed that the NAPs process is still in the phase of formal adaptation and there is no 'real' reformulation of national policy objectives. Particularly relevant in this case is the fact that at the European level France retains a high degree of manœuvre and has directly influenced the drafting of the EPGs. Under the French Presidency of the European Union, in fact, the government representatives have been continuously pushing for introducing more emphasis on the concept of quality of work. As a result new horizontal objectives were introduced in the $2001 \mathrm{EPGs}$, which also included quality of work. ${ }^{84}$ The studies conducted thus confirm that the intergovernmental element in the Strategy is very strong. In Spain the Luxembourg process has promoted a re-thinking of policy-making by fostering the co-ordination between different administrations and the rationalization of employment and labour-market policies, one important aspect being the increase in expenditure for employment-related policies. However, case studies showed that the EES is insufficient per se due to particular political patterns and to the existence of

${ }^{80}$ For Sweden and Denmark see K. Jacobsson and H. Schmid, 'Real Integration or just Formal Adaptation?-On the Implementation of the National Action Plans for Employment' in de la Porte and Pochet, above n. 36, 69-95; M. Junestav, 'Labour Cost Reduction, Taxes and Employment: The Swedish Case' in de la Porte and Pochet (eds.), above n. 36, 137-75; for France, see G. Coron and B. Palier, 'Changes in the Means of Financing Social Expenditure in France since 1945' in de la Porte and Pochet (eds.), above n. 36, 97-136; for Spain, see J. Gonzaléz-Calvet, 'Employment Policies in Spain: From Flexibilisation to the European Employment Strategy' in de la Porte and Pochet (eds.), above n. 36, 177-221.

${ }^{81}$ See K. Anderson, 'The Europeanisation of Pension Arrangements: Convergence or Divergence?' in de la Porte and Pochet (eds.), above n. 36, 256.

82 See Jacobsson and Schmid, above n. 80, n. 70. The authors argue that EES is 'a rather insular process of interaction' between administrative top-level professionals and civil servants in the Directorate General of Employment and Social Affairs and national ministries'.

83 Ibid., 86-7.

${ }^{84}$ See Council Decision of 19 Jan. 2001 on Guidelines for Member States' employment policies for the year $2001(2001 / 63 / \mathrm{EC})$. 
persisting structural problems. With regard to the involvement of the social partners in the adoption and implementation of the NAPs, most social partners have reported positively on the Luxembourg Process. Whereas participation in the shaping of the NAPs was considered insufficient in the early years of the Strategy, recent evidence shows that there is greater participation, although the degree of the social partners' contribution varies according to the area taken into consideration. ${ }^{85}$

However, the role of the social partners is still unsatisfactory, still being far from proper negotiation and consultation with the government. This situation contrasts with the EPGs particularly with regard to areas covered by the old 'Adaptability' pillar, where the social partners are given a key role in the modernization of work organization and in lifelong learning measures. ${ }^{86}$ Moreover, the NAPs reveal that it is mostly national confederations that are involved in the process, and little information is provided on the extent of the social partners' participation at the sectoral level. ${ }^{87}$ In addition, several national union confederations report having less than two weeks to provide input into plans or reports and that no real effort has been made for their participation in the process. ${ }^{88}$ Finally, there is scant information on the interaction between national and European social partners in the development of the Strategy. The ETUC ${ }^{89}$ is said to have been insufficiently involved..$^{90}$

Lafoucrière argues that the effective implementation of policies under the then 'Adaptability' pillar could be guaranteed only by the wider use of 'positive social dialogue', i.e., by introducing more specific guidelines, which are currently too vague, and by defining more clearly an active role for the social partners in the EES. ${ }^{91}$

One final point concerns the obligation that Member States have to exchange best practices. With the beginning of the second annual cycle of the NAPs, Member States have been required to present examples of best practices. The achievement of this target has not been fully successful. Although the JER lists a few examples of best practices, the method used for the sharing of best practices consists in the review of the NAPs of those Member States

85 See Commission Staff Working Paper, above n. 85; see also European Commission, above n. 75.

86 See G 13, G 14, and G 15. See also G 6 (combating emerging bottlenecks); G 17 (equal opportunities); G 18 (reconcile work and family life); and Horizontal Objectives B (Quality of Work); C (Lifelong Learning Strategy); D (partnership); F (common structural indicators).

87 See B. Keller and M. Bansbach, 'Social Dialogues: An Interim Report on Recent Results and Prospects' [1999/2000] Industrial Review Journal Annual Review 84. For information on the European sectoral level see: www.eiro.eurofound.ie/2002/01/Feature/EU0201236F.html. It is not clear, at the European level, how the joint declarations adopted in each sector are then channelled in the wider context of the European social dialogue.

88 See Joint Report by UNICE, UEAPME, CEEP, and ETUC, 'Factors for success: a compendium of social partners' initiatives relating to the employment guidelines' in ETUC Resolution on the 'EU Employment Guidelines 2001', 25-26 Oct. 2000, 3, (online) available at: www.etuc.org/en/index. cfm?target=/EN/Decisions/execlom/Resolutions/English/0010_employmentguidelines2001.cfm.

89 i.e., European Trade Union Confederation.

90 See ETUC, Luxembourg Process: ETUC Employment Fiches (2001), available online at: www.etuc.org.

91 See Lafoucrière, above n. 31, 31; see also 22-4 and 29-31. 
which have not given enough details of best practices, which are then circulated to all Member States. Moreover, the NAPs dedicate a section to best practices only in the appendix, which is usually only two to three pages long. The Commission has therefore started a series of meetings with representatives of the national governments to identify best practices and promote their exchange between all the Member States. Hence, NAPs have not only to be submitted to the Commission but also made available to the representatives of all the Member States for comparison and evaluation. While this does certainly promote peer review, the whole session allocated to each National Plan is only of one hour. The session includes a brief presentation by the Member State, comments by two other Member States, and discussion. Thus it is necessary to review these learning policy mechanisms in order to make them more effective.

The EES therefore has various weaknesses that are inherent in its soft-law nature. For the purpose of this chapter I will highlight those which, from the viewpoint of EU governance, hinder its potential ability to be an alternative mode of governance. First, the very nature of the Employment Strategy as a non-binding legal instrument does not allow for accurate assessment of the results achieved, given that national measures may not be based on the EPGs to be adopted and that many elements of the EES are already part of national policy programmes. Secondly, the subordination of EES implementation to the economic and political situations within the various Member States, combined with its soft-law nature, does not guarantee its further development in moments of economic recession or political instability. Moreover, the paucity of specific procedural rules and detailed guidelines, the scant information on the operationalization of the exercise of benchmarking - particularly on how parameters and structural indicators are selected and applied the absence of a clear definition of the distribution of competence, ${ }^{92}$ particularly at the national level, and, finally, the lack of a system of legal or formal sanctions in the event of non-alignment of a given Member State with the EPGs seriously undermine the legitimacy and the effectiveness of the Strategy as a form of deliberative supra-nationalism ${ }^{93}$ considering that the guidelines are normative in character. ${ }^{94}$ The whole process seems in fact to be taking place between 'elites for elites'. ${ }^{95}$ Moreover, both the EU Parliament and the Committee of the Regions have been given a minor consultative role in the overall implementation $^{96}$ and the European Court of Justice (ECJ) is absent from the process.

92 See Szyszczak, above n. 32, 1138.

93 See D. Hodson and I. Maher, 'The Open Method of Co-ordination as a New Mode of Governance: The Case of Soft Economic Policy Co-ordination' (2001) 39 JCMS 730-2.

${ }^{94}$ See M. Biagi, 'The Impact of European Employment Strategy on Role of Labour Law and Industrial Relations' [2000] International Journal of Comparative Labour Law and Industrial Relations 160.

95 See C. Barnard and S. Deakin, 'Corporate Governance, European Governance and Social Rights', paper presented at 'Fundamental Social Rights: a conference to mark the 40th anniversary of the introduction of a course on Industrial Law (later called Labour Law) in Part II of the Cambridge Law Tripos', University of Cambridge, 21 July 2001.

96 See Szyszczak, above n. 32, 1141. 
The above 'underlines the opacity and complexity of the institutional framework'. ${ }^{97}$ The EES/OMC therefore 'may lead to the formal reassignment of policy powers from the national to the EU level and hence may not provide durable alternative to the traditional EU model'. 98

\section{Bridging the Gap between Titles VIII and XI: A Normative Reconstruction of the European Employment Strategy}

\section{A. INTRODUCTION: LA CITOYENNETÉ SOCIALE EUROPÉENNE, CONSTITUTIONALISM AND EU GOVERNANCE}

The adoption of the EU Charter of Fundamental Rights, ${ }^{99}$ the Laeken Declaration, ${ }^{100}$ coupled with the setting up of a Convention charged with considering the future of the European Union, ${ }^{101}$ and the 2004 IGC $^{102}$ have fostered the debate about a European Constitution and a catalogue of rights to be included in the EC Treaty. ${ }^{103}$

These events illustrate how constitutional issues have become strictly intertwined with the discourse of rights and citizenship. ${ }^{104}$ More importantly, they emphasize how the European Union has decisively gone beyond its exclusive nature of an economic union, the Community top priority being the transformation of the European Union into a renovated and strengthened $q u a s i$-state polity. The European Union is in fact searching for new ideas on how to 're-dress' its own political identity and image. Consequently, particular emphasis is given to a 'EU citizenship practice' 'understood as the action that

97 See Hodson and Maher, above n. 93, 730-2. $\quad 98$ Ibid.

99 The Charter was issued by joint act of the European Parliament, the Council of the European Union, and the European Commission on 7 Dec. 2000 (see [2000] OJ C364/1) and came into force on 26 Feb. 2001. The Charter lists 50 specific rights apart from the general provisions contained in Arts. 51-54. These rights are subdivided into 6 chaps.: Chap. I 'Dignity', Arts. 1-5; Chap. II 'Freedoms', Arts. 6-19; Chap. III 'Equality', Arts. 20-26; Chap. IV 'Solidarity', Arts. 27-38; Chap. V 'Citizens' Rights', Arts. 39-46; and Chap. VI 'Justice', Arts. 47-50. For further documentation on the Charter visit the EU website at URL: http://europa.eu.int/comm/justice_home/unit/charter/ index_en.html; see also the European Parliament special website at: www.europarl.eu.int/ charter/default_en.htm.

100 See Presidency Conclusions of the European Council, Laeken, 14 and 15 Dec. 2001, Annex I, 1-9.

101 For information and analysis of the workings of the Convention on the Future of the European Union and, more broadly, to follow the constitutional debate on the EU see the website of the Federal Trust for Education and Research at: www.fedtrust.co.uk/eu_constitution.

102 Ibid., 8.

103 There is a vast amount of literature on both issues. For an analytical study of the EU Charter see Report of the Comité des Sages, For a Europe of Civic and Social Rights (European Commission, Brussels, 1996); Report of the Expert Group on Fundamental Rights, Affirming Fundamental Rights in the European Union, Time to Act (European Commission, D-G for Employment \& Social Affairs, Brussels, 1999). For a detailed account of constitutionalism issues see P. Craig, 'Constitutions, Constitutionalism and the European Union' (2001) 7 ELJ 125-50.

104 See European Parliament, Committee on Constitutional Affairs, Report on 'The Constitutionalisation of the Treaties', Session Document, 12 Oct. 2000, Final, A5-0289/2000; see also Commission Communication, 'A Basic Treaty for the European Union', COM(2000)434 final. 
contributes to the establishment of citizenship rights, access and belonging in a community'. ${ }^{105}$ In this respect, the modernization of the European Social Mode $^{106}$ has fuelled the debate about a European droit social paving the way towards the development of the concept of 'citizen-worker' as opposed to 'market citizen', ${ }^{107}$ who is granted a specific set of civil and social as well as economic rights. ${ }^{108}$ The conceptualization of EU citizenship is far from an easy enterprise. EU citizenship ${ }^{109}$ represents an institutional challenge with an evolving dimension. Its development in fact cannot be separated from the broader process of Europeanization. ${ }^{110}$ The main difficulty consists in the fact that citizenship is a premise for statehood, ${ }^{111}$ and because the European Union is a non-state polity, the sources for a definition of EU citizenship necessarily lay somewhere between citizenship and nationality. The trait d'union is the protection of fundamental rights ${ }^{112}$ and, more broadly, the catalogue of human rights embedded in the constitutional traditions of the Member States and further developed in the European Union, ${ }^{113}$ which has been transformed

105 See A. Wiener, 'The Developing Practice of "European Citizenship” ' in M. La Torre (ed.), European Citizenship: An Institutional Challenge (Kluwer Law International, The Hague, London, Boston, 1998), 392. See also Presidency Conclusions of the Cologne European Council of 3 and 4 June 1999, Annex IV, para. 1: 'To establish a Charter of fundamental rights in order to make their overriding importance and relevance more visible to the Union's citizens.... The European Council believes that this Charter should contain fundamental rights and freedoms as well as basic procedural rights. In drawing such a Charter account should furtnermore be taken of economic and social rights as contained in the European Social Charter and the Community Charter of the Fundamental Social Rights of Workers (Article 136 TEC), insofar as they do not merely establish objectives for action by the Union' (emphasis added).

106 See Communication from the Commission to the Council, the European Parliament, the Economic and Social Committee, and the Committee of the Regions, 'Social Policy Agenda', $\operatorname{COM}(2000) 379$ final.

107 See A. Marias Epaminondas, 'From Market Citizen to Union Citizen' in A. Marias Epaminondas (ed.), European Citizenship (European Institute of Public Administration, Maastricht, 1994), 1-24.

108 Civil and political rights have, both in theory and in practice, received full recognition, whereas economic and social rights are still the subject matter of very heated debates. See A. Eide, C. Krause, and A. Rosas (eds.), Economic, Social and Cultural Rights: A Textbook (Martinus Nijhoff, Dordrecht, 1995) 15; M. Scheinin, 'Economic and Social Rights as Legal Rights' in ibid., 41-62.

109 See Arts. 17-22 EC.

110 See Szyszczak, above n. 32, 1161-2. Szyszczak shows how the new social policy paradigm has recently informed the human rights and citizenship discourse within the EU legislative practice. Two directives are illustrative: Council Directive 2000/78/EC establishing a general framework for equal treatment in employment and occupation [2000] OJ L303/16; and Directive 2000/43 on race discrimination [2000] OJ L180/22.

111 See J. Weiler, 'The State über alles. Demos, Telos and the German Maastricht Decision', Jean Monnet Working Paper, No. 6/95, available online at: www.jeanmonnetprogram.org/papers/ papers95.html.

112 See D. O'Keeffe and A. Bavasso, 'Fundamental Rights and the European Citizen' in La Torre (ed.), above n. 105, 255.

113 See Case 186/87 Ian William Cowan v. Trésor Public [1989] ECR 216; Case C-85/96 María Martínez Sala v. Freistaat Bayern [1998] ECR I-2709. These two cases illustrate the nexus between EU citizenship and fundamental rights. In these two decisions the Court linked Art. 12 EC, discrimination on grounds of nationality, to the freedom of movement principle in order to protect and broaden the scope of national social rights vis-à-vis EU citizenship. See also Case C-184/99, Grzelczyk [2001] Rec. I-6193, (online) available at: www.cria.eu.int/common/recdoc/indexaz/en/ c2.htm. 
from an international Treaty to a constitutional legal order. ${ }^{114}$ Within the process of European integration EU citizenship promotes not only the economic role but also the constitutional role of the individual. ${ }^{115}$ The latter in fact is situated in a polity characterized by a weak political core, multi-level networks, and changed capital/labour relations, ${ }^{116}$ which is now aiming to achieve a clear identity and legitimacy of its own deriving from below.

The ECJ has played a pivotal role in marking the gradual shift towards a social dimension of rights ${ }^{117}$ in its process of constitutionalization of the Treaty, including the protection of fundamental rights, notably in the area of the free movement of persons and equal treatment between men and women. ${ }^{118}$ The Stauder ruling in fact made it clear that fundamental rights are part of the general principles of Community law and protected by the Court. ${ }^{119}$ In addition, the development of general principles of EU law such as proportionality, horizontal direct effect, equality, and non-discrimination have had an important role in substantiating the Treaty provisions in social policy. ${ }^{120}$

The Court has had a major role, not only in fostering social rights ${ }^{121}$ through the enforcement of EC law, but also in the actual creation of European social rights, ${ }^{122}$ although the rationale of its case law has not always been coherent. Acting on the basis of what has been defined as 'purposeful opportunism', ${ }^{123}$ the Court has in fact used the 'language of rights' with caution and in a piecemeal way. ${ }^{124}$ Its case law has greatly contributed to the drafting of the EU Charter. The Court in fact has also interpreted directly non-social European acts in order to guarantee the social protection of EU nationals. In the decisions made in the Walrave and Koch, ${ }^{125}$ Bosman, ${ }^{126}$ and, more recently,

114 See Case 26/62 Van Gend en Loos v. Nederlandse Administratie der Belastingen [1963] ECR 1, 11-13; G.F. Mancini, 'The Making of a Constitution for Europe' (1989) 26 CMLRev. 595.

115 See O'Keeffe and Bavasso, above n. 112, 262.

116 See J. Caporaso, 'The European Union and Forms of State: Westphalian, Regulatory or PostModern?' (1996) 34 JCMS 45-8.

117 See Case 43/75 Defrenne v. Société Anonyme Belge de Navigation Aerienne (SABENA) [1976] ECR 455, [1976] 2 CMLR 98, para. 10, where the Court stated that the Community is not only an economic union but is also intended to ensure social progress and seek to improve the living and working conditions of European citizens.

118 See B. De Witte, 'The Past and Future Role of the European Court of Justice in the Protection of Human Rights' in P. Alston, M. Bustelo, and J. Heenan (eds.), The EU and Human Rights (OUP, Oxford, 1999), 859-97. See also P. Craig and G. de Búrca, EU Law, Text, Cases and Materials (3rd edn., OUP, Oxford, 2003) chaps. 7, 16, 19.

119 See Case 29/69 Stauder v. City of Ulm [1969] ECR 419, 425. $\quad 120$ Ibid.

121 See Szyszczak, above n. 32, 1164-7 for an analysis of the impact of the new social policy paradigm on the Court's case law.

122 See K. Lenaerts and P. Foubert, 'Social Rights in the Case-Law of the European Court of Justice, The Impact of the Charter of Fundamental Rights of the European Union on Standing Case-Law' (2001) 28 LIEI 267-96.

123 See D. Wincott, 'The Role of Law or the Rule of the Court of Justice? An Institutional Account of Judicial Politics in the European Community' (1995) 2 JEPP 583.

124 See G. de Búrca, 'The Language of Rights and European Integration' in J. Shaw and G. More (eds.), New Legal Dynamics of the European Union (Clarendon Press, Oxford, 1995) 39-43.

${ }_{125}$ See Case 36/74 B.N.O. Walrave and L.J.N. Kock v. Association Union Cycliste Internationale, Koninklijke Nederlandsche Wielren Unie and Federación Española Ciclismo [1974] ECR 1405.

126 See Case C-415/93 Union Royale Belge des Sociétés de Football Association ASBL and others v. Jean Marc Bosman and others [1995] ECR I-4921. 
Angonese ${ }^{127}$ and Ferlini ${ }^{128}$ cases the Court has contributed to the fight against discrimination perpetrated against EU employees, and in doing so it was indirectly influenced by the freedom to choose an occupation and the right to engage in work, which are now also protected by Article 15 of the EU Charter. The influence of the Court's case law can also be seen with regard to Article 34 of the EU Charter in the Decker ${ }^{129}$ and Kohll ${ }^{130}$ judgments, where the Court highlighted the importance of the fundamental principle of freedom of movement, but also aimed to safeguard social security systems when stating that the financial balance of social security systems may constitute an 'overriding reason capable of justifying a barrier of that kind'. ${ }^{131}$

Lenaerts and Foubert argue that the 'EU Charter constitutes a neutral confirmation of the rights' 132 it intends to safeguard because its scope is limited a priori by Article 52(2) of the Charter. ${ }^{133}$ I do not entirely agree with this statement. I will explain this by analysing the EU Charter and the OMC together.

Both the Charter and the OMC have been conceived as 'dynamic soft law instruments', ${ }^{134}$ which promote the Europeanization process 'by building upon and around the aquis'135 without directly affecting the extant institutional design. Moreover, similarities may be drawn between the provisions of Articles $51^{136}$ and 52(2) of the Charter and the White Paper on 'EU Governance', in the part where it says that the OMC does not supplant but supplement the Community Method. ${ }^{137}$ However, whilst the wording of the White Paper is explicit, i.e., the OMC 'should be a complement rather than a replacement for

127 See Case C-281/98 Roman Angonese v. Cassa di Risparmio di Bolzano SpA [2000] ECR I-4139.

128 See Case C-411/98 Angelo Ferlini v. Centre Hospitalier de Luxembourg [2000] ECR I-8081.

129 See Case C-120/95 Nicolas Decker v. Caisse de Maladie des Employés Privés [1998] ECR I-1871.

130 See Case C-158/96 Raymond Kohll v. Union des Caisses de Maladie [1998] ECR I-1935.

131 See Case C-120/95, above n. 129, para. 39; Case C-158/96, above n. 130, para. 41.

132 Ibid., 293-6. The authors develop their thesis by analysing and comparing the provision contained in Art. 21(1) of the Charter and Art. 13 EC, both regarding the prohibition of discrimination (except discrimination based on nationality, the prohibition of which is sanctioned in Arts. 12 EC and 21(2) of the Charter) and by looking at the Grant judgment: Case C-249/96 Lisa Jacqueline Grant $v$. South-West Trains Ltd. [1998] ECR I-636. The authors argue that even though the provision of Art. 21(1) of the Charter has a broader scope its effective implementation is hindered by the provision contained in Art. 52(2) of the Charter. They conclude by stating that Ms Grant would probably not have benefited so easily from the EU Charter were it in force at the time of the judgment.

133 Art. 52(2) of the Charter provides that 'rights recognised by this Charter, which are based on the Community Treaties or the Treaty on European Union shall be exercised under the conditions and within the limits defined by those Treaties'.

${ }_{134}$ See J. Kenner, 'The Charter of Fundamental Rights of the European Union-A Panacea for European Social Law?', ECSA Seventh Biennial International Conference, Madison, Wisc., 31 May-2 June 2001, 11; and for a deeper analysis of the Charter as a non-binding legal instruments see also $12-15$. 135 Ibid., 12-13 (emphasis added).

136 Art. 51 of the Charter provides that: 'The provisions of this Charter are addressed to the institutions and bodies of the Union with due regard for the principle of subsidiarity and to the Member States only when they are implementing Union law. They shall therefore respect the rights, observe the principles and promote the application thereof in accordance with their respective powers. This Charter does not establish any new power or task for the Community or the Union, or modify powers and tasks defined by the Treaties' (emphasis added).

$137 \mathrm{COM}(2001) 428,21$. 
Community action', ${ }^{138}$ the same cannot be said about the horizontal provisions of the Charter. In fact, whereas the combined reading of Articles 51 and 52(2) of the Charter seems to suggest a limitation of the scope of the Charter with regard to the creation of new powers within the Community or the Union and the extent of the exercise of the rights recognized in the Charter, the provision of paragraph 3 of Article 52 of the Charter allows for a different interpretation altogether. The fact that EU law may provide more extensive protection of the rights contained in the Charter than the European Convention on Human Rights and Fundamental Freedoms (ECHR) may be interpreted as meaning that the European institutions may in the future agree to establish new powers or tasks for the Community or the Union with regard to the protection of the rights sanctioned in the Charter. This contention is further strengthened by the fact that in the draft Constitutional Treaty the Charter has been inserted as Part II of the Treaty, and has therefore become legally binding. ${ }^{139}$ It is to be hoped that this will be the case since not only individual and group standing to challenge Community measures directly before the Court through the means of Article 230 EC is, and has been, extremely restrictive but the ability of the individual to challenge an EU measure for a breach of the ECHR depends on whether the measure has already been implemented at the national level. ${ }^{140}$

Previously, I showed how the Court's case law has influenced the drafting of the Charter. At the same time, however, the EU Charter also represents a valuable interpretative tool for the Court, which will continue to have an important constitutionalization role in the area of fundamental rights. ${ }^{141}$ The Court of First Instance has already referred to Articles 41 and 47 of the EU Charter ${ }^{142}$ in various cases. ${ }^{143}$ Hence, there is a dialectical relationship and mutual influence between the EU Charter and the case law of the Court. In fact, with regard to social policy sensu lato the inclusion of the freedom of assembly and association, the right to information and consultation, and the right to collective bargaining and action in the EU Charter ${ }^{144}$ is particularly relevant to

$138 \operatorname{COM}(2001) 428,21$.

139 See European Convention, Draft Treaty establishing a Constitution for Europe, CONV 820/1/03, REV 1, Brussels, 27 June 2003 (01.07), Part II. $\quad 140$ See Art. 51 of the EU Charter.

141 The importance of the EU Charter in the case law of the Court is highlighted by the Opinion of Tizzano AG in the BECTU case, where in addressing the Charter's status the AG said that: 'it includes statements, which appear in large measure to reaffirm rights, which are enshrined in other [international] instruments. I think therefore that, in proceedings concerned with the nature and scope of a fundamental right, the relevant statements of the Charter cannot be ignored; in particular, we cannot ignore its clear purpose of serving, where its provisions so allow, as a substantive point of reference for all those involved, Member States, institutions, natural and legal persons, in the Community context'. See Opinion of Tizzano AG delivered on 8 Feb. 2001 in Case C-173/99 Broadcasting, Entertainment, Cinematographic and Theatre Union (BECTU) $v$. Secretary of State for Trade and Industry [2001] ECR I-4881 paras. 27-28; see also paras. 22-28.

142 Right to a good administration and right to an effective legal remedy respectively.

143 See Case T-54/99 Max.mobil v. Commission, judgment of 30 Jan. 2002, paras. 48 and 57 (Arts. 41 and 47 of the Charter); Case T-198/01R Technishce Glaswerke, order of 4 Apr. 2002, para. 85 (Art. 41 of the Charter), and Case T-177/01 Jégo-Quéré et Cie v. Commission, judgment of 3 May 2002, para. 47 (Art. 47 of the Charter).

144 See Arts. 12(1), 27, and 28 of the Charter. 
the discourse of EU Governance, and it broadens the logic of the acquis communautaire in the area of social policy. Their inclusion may in fact help to overcome the inadequacy of the legislative competence in relation to transnational matters at the EU level. In this respect, Sciarra had already argued before the adoption of the EU Charter that the insertion of the right to organize in the EU fundamental social rights would strengthen the position, representativity, and standing of supranational associations. ${ }^{145}$

The drafting of these provisions has been particularly difficult as they reflect the diversity of Member States' labour markets and industrial relations system and the limited scope of EU competence. ${ }^{146}$ What follows is a brief analysis of the three provisions regarding the freedom of assembly and association, the right to information and consultation, and the right to collective bargaining and action. Article $12^{147}$ is consistent with the Court's case law. ${ }^{148}$ The right to information and consultation is the only right among the three that has already been the subject of legislation at the EU level. ${ }^{149}$ The wording of Article 27 has been subject to various criticisms. Hepple argues that the provision fails, in the first place, to explain whether the workers' right to information and consultation within an undertaking is clearly a 'right' or a mere objective and, secondly, it fails to determine at what level the right can be exercised. ${ }^{150}$ Moreover, the provision weakens the effective exercise of the right by making it dependent upon Community and national law. ${ }^{151}$ Article 28 has gone well beyond the rights which have been recognized in Community law; ${ }^{152}$ however, there is a lack of detail as to what the rights entail. Secondly, the provision, parallel to Article 27, seems to suggest that the bearers of the rights 'workers and employers', or 'their respective organization' are alternatives. Bercusson further criticizes the ambiguity that follows from such wording because, particularly in the case of collective action, the right of workers

\footnotetext{
145 See S. Sciarra, 'From Strasbourg to Amsterdam: Prospects for the Convergence of European Social Rights Policy' in Alston, Bustelo, and Heenan (eds.), above n. 118, 500-1.

${ }^{146}$ In this respect see B. Bercusson, 'Fundamental Trade Union Rights in the European Union' in L. Betten and D. Mac Devitt (eds.), The Protection of Fundamental Social Rights in the European Union (Kluwer Law International, The Hague, London, Boston, 1996), 93-6, who argues that 'the prospect of trade union rights enshrined in EU law is usually said to aspire to neutrality of impact on national systems' (at 94). More precisely, the author argues that 'neutrality is premised not only on the desirability of national autonomy and trade union autonomy (vertical and horizontal autonomy). It also implies an established balance of forces in industrial relations' (at 95).

147 According to the Explanations Relating to the Complete Text of the Charter, prepared by the Presidency of the Convention, which drafted the Charter Art. 12(1) corresponds to Art. 11 ECHR.

148 See Case C-415/93 Union Royale Belge des Sociétés de Football Association ASBL and others v. Jean Marc Bosman and others [1995] ECR I-4921, para. 79, where the Court recognized that the freedom of association as set out in Art. 11 ECHR is a fundamental principle which Community law respects. See also Jacobs AG's single Opinion in Case C-67/96 Albany International, Joined Cases C-115/97, C-116/97, \& C-117/97 Brentjens and Case C-219/97 Drijuende Bokken [1999] ECR I-5751, para. 139, where the AG came to the same conclusion.

149 See Directive 2002/14/EC [2002] OJ L80/29.

150 See B. Hepple, 'The EU Charter of Fundamental Rights' (2001) 30 ILJ 229-30.

151 See B. Bercusson, 'A European Agenda?' in K. Ewing (ed.), Employment Rights at Work (Institute of Employment Rights, London, 2001), 168.

152 Compare this with the Opinion of Jacobs AG, above n. 148, paras. 158-60.
} 
to engage in industrial action is not stated clearly. ${ }^{153}$ Article 28, however, may help to shed new light on issues concerning the legislation adopted pursuant to Article 139 EC, particularly questions relating to the representativity of the social partners. It may also be used to exempt collective agreements from Article 81 EC. Finally, Articles 12 and 28 of the EU Charter may contrast with Article 137(6) EC, which denies legislative action in relation to, inter alia, the right of association, and the right to strike and to impose lockouts. Legislation at the European level could be adopted to solve this legal conundrum.

Notwithstanding the issues that may arise with regard to the above Articles of the Charter, the joint reading of Articles 12, 27, 28, and 47 may, nevertheless, be used to argue for a less restrictive approach to the rules of locus standi of trade associations and works councils. The Court's case law in fact has been incoherent, sometimes subjecting social policy to securing the functioning of the Internal Market, particularly in the area of collective action and collective bargaining. ${ }^{154}$ In the Maurissen case $^{155}$ the Court defined the freedom of association of Community officials as a 'general principle of labour law applicable within the Community legal order'. ${ }^{156}$ On the contrary, in Commission $v$. France the Court subjected the right to collective action and freedom of association to the free movement of goods. ${ }^{157}$ In three Dutch cases, ${ }^{158}$ the Court stated that collective agreements concluded with the aim of social policy objectives by virtue of their nature and purpose do not fall within the scope of EC competition rules. ${ }^{159}$ Thus the Court seems to have suggested that in some situations the social dimension per se may take priority over the economic dimension. A deeper analysis of the rulings, however, reveals a different picture. In particular, in the Albany case the Court's reading of some provisions of the Treaty is subject to severe criticism. ${ }^{160}$ As Vousden aptly argues, 'the Court's

153 See Bercusson, above n. 151, 170.

154 See P. Syrpis, 'Smoke Without Fire: The Social Policy Agenda and the Internal Market' (2001) 30 ILJ 271-88. The author analyses the OMC in the light of the internal market case law, in particular Case C-376/98 Germany v. European Parliament and Council [2000] ECR I-8419 (the 'Tobacco Advertising Directive' case). The author argues that for the new forms of governance to have success in the long term the Court has to change its understanding of what is required for the proper functioning of the internal market and that, in particular, differences between Member States do not hinder the internal market.

155 See Joined Cases C-193/87 \& C-194/87 Henri Maurissen and European Public Service Union $v$. Court of Auditors of the European Communities [1990] ECR I-114. 156 Ibid., para. 20.

157 See Case C-265/95 [1997] ECR I-6959. See G. Orlandini, 'The Free Movement of Goods as a Possible “Community” Limitation on Industrial Conflict' (2000) 6 ELJ 341.

158 See Joined Cases C-115/97 \& C-117/97 Brentjens' Handelsonderneming BV $v$. Stichting Bedrijfspensioenfonds voor de Handel in Bouwmaterialen [1999] ECR I-6025; Case C-219/97 Maatschappij Drijvende Bokken BV v. Stichting Pensioenfonds voor de Vervoer- en Havenbedrijven [1999] ECR I-6121; Case C-67/96 Albany International BV v. Stichting Bedrijfspensioenfonds Texttielindustrie [1999] ECR I-5751.

159 See para. 60 of Albany; para. 57 of Brentjens'; para. 47 of Drijvende Bokken, all above n. 158. See also Case C-222/98 Van der Woude [2000] ECR I-7111, para. 25, where the Court held that a collective agreement providing for employee health insurance also benefited from the Albany ruling, since it helped to improve the working conditions by ensuring that employees could meet medical expenses while reducing the costs of insurance.

160 See S. Vousden, 'Albany, Market Law and Social Exclusion' (2000) 29 ILJ 181-91. The reference to (old numbering): Art. 3 EC is made without taking into consideration the European Social 
exemption of the collective agreements from the scope of Article 81 EC was justified on the ground that the subject matter of such agreementsremuneration-made direct contribution to the improvement of the working conditions'. ${ }^{161}$ Moreover, the 'reasoning does not clearly distinguish between national and European law or between national and European social partners. It also implies that collective agreements do not violate competition law if they are stipulated in the context of the traditional subject matter of collective bargaining, i.e. wage and working conditions'. ${ }^{162}$ This implies that national measures aiming to modernize the organization of work outside these traditional patterns may fall foul of Article 85 EC. ${ }^{163}$ Thus not only is social policy sensu lato still subject to competition law, ${ }^{164}$ but some of the objectives of the Employment Strategy, namely those of the then 'Adaptability' pillar, may be seriously undermined. The issues raised by the Albany case, namely the sensitivity of Member States to social security issues and, more broadly, to social policy, together with the diversity of labour market and IR systems; the limited competence of the Community in this sensitive policy area, and the problems linked to the maintenance of the principle of subsidiarity; the status of national collective bargaining and the problems of identifying a clear borderline between the European Social Dialogue and national social partners; ${ }^{165}$ the lack of a comprehensive dialectical relationship between national and EU social partners, and finally the difficulty of creating a continuum between previous methods of policy-making, tradition, and new governance lead us to the issue regarding the role of the social partners and the 'absence' of the EU Parliament in the framework of new governance, which further buttresses the need to introduce amendments to the EC Treaty.

\section{B. POLICY-MAKING IN THE EUROPEAN SOCIAL DIALOGUE}

Since the Val Duchesse Agreement the social partners have gained a quasiinstitutional role within the EU decision-making process. ${ }^{166}$

Barnard ${ }^{167}$ explains exhaustively the evolving role of the social partners at both the European and national levels. In particular, she analyses the

Fund; Arts. 117-120 EC is made without taking into account that these provisions refer to the European social partners and not national social partners; Art. 4(1) and (2) of the Social Policy Agreement without considering that these agreements may fall outside Art. 173 EC.

$$
161 \text { Ibid., 182. } 162 \text { Ibid., } 189 . \quad 163 \text { Ibid., 189-90. }
$$

164 See T. Hervey, 'Social Solidarity: A Buttress Against the Internal Market Law?' in Shaw, above n. 7, 33-43. See also C. Barnard and S. Deakin, 'In Search of Coherence: Social Policy, the Single Market and Fundamental Rights' (2000) 31 ILJ 331-45.

165 A. Lo Faro, Regulating Social Europe, Reality and Myth of Collective Bargaining in the EC Legal Order (Hart Publishing, Oxford, 2000), 5 and 18-19, where the author explains the impossibility of describing EC labour law as a 'self-contained and homogeneous system of norms endowed with an autonomous rationality of its own', and thus the legitimization from above, which Community bargaining enjoys, entails the use of an a contrario process in order to explain the functional difference between the latter and national collective bargaining.

166 See J. Dølvik, 'The ETUC and Development of Social Dialogue and European Negotiations after Maastricht', ARENA Working Papers 97/2, available online at: www.arena.uio.no/.

167 See C. Barnard, 'The Social Partners and the Governance Agenda' (2002) 8 ELJ 80-101. 
reasons that lead to the involvement of the social partners in the EU law and policy-making process and the weaknesses and paradoxes of their inclusion vis-à-vis the new governance agenda. Barnard identifies the main issues regarding the quasi-public role of the social partners and the lack of the official inclusion of the EU Parliament ${ }^{168}$ in the European collective bargaining system. ${ }^{169}$ The issues identified are: subsidiarity, effectiveness, legitimacy, and democracy.

As regards subsidiarity, the main contention is that the inclusion of the social partners is an example of centralized law-making or, more aptly, a form of 'centrally co-ordinated decentralization', ${ }^{170}$ rather than a development of the principle of subsidiarity in the area of social policy. In respect of effectiveness the introduction of the social dialogue at the European level represented one of the means of confronting the 'sclerosis' of the traditional legislative process or, more critically, a way of 'defusing' the problem of effectiveness of Community law.

Five Directives have been adopted by the European Social Dialogue; ${ }^{171}$ however, the result achieved so far has not been very satisfactory in terms of transparency, efficiency, and output. In fact, it has not resolved important procedural problems, e.g., the negotiations between the Social Partners on

168 For a critical analysis see L. Betten, 'The Democratic Deficit of Participatory Democracy in Community Social Policy' (1998) 23 EL Rev. 20; K. Armstrong, 'Governance and the Single European Market' in P. Craig and G. de Búrca, The Evolution of EU Law (OUP, Oxford, 1999), 769-70; European Parliament Resolution on the New Social Dimension of the Treaty on European Union, A3-0091/94 [1994] OJ C77/30.

169 This legislative procedure introduced at Maastricht can be summarized as follows: the Commission consults management and labour about the possible direction of Community action (first consultation). If it decides to proceed, the Commission then consults the social partners on the content of the envisaged proposal (second consultation). On the occasion of such consultation, the social partners may inform the Commission of their desire to negotiate an agreement. This process, authorized by the Commission, suspends the Commission's initiative with regard to a specific Community action for 9 months, unless the social partners together with the Commission decide jointly to extend it.

The EU Social Dialogue is thus based on a binary scheme procedure, which, starting with the consultation of the social partners, may lead to: (a) strict co-operation of management and labour with the Commission and the Council; or (b) the total or partial regulation of a specific issue through the adoption of a collective agreement. In the latter case, collective agreements are considered a source of law, subsidiary to the typical EU decision-making process. See Arts. 138 and 139 EC. For more details see C. Barnard, EC Employment Law (OUP, Oxford, 2000).

170 See A. Ferner and R. Hyman, 'Introduction: Towards European Industrial Relations' in A. Ferner and R. Hyman (eds.), Changing Industrial Relations in Europe (Blackwell, Oxford, 1998), p. xvi; J. Weiler, 'European Democracy and its Critics: Polity and System' in his The Constitution of Europe (CUP, Cambridge, 1999); Lo Faro, above n. 165, chaps. 3-6.

1713 Directives regarded the inter-sectoral level: see Directive 96/34/EC [1996] OJ L145/9, as amended and extended to the UK, Directive 97/75/EC on parental leave [1998] OJ L10/24, which was based on the Framework Agreement between UNICE, CEEP, and ETUC [1996] OJ L145/4; Directive 97/81/EC on part time work [1998] OJ L14/9, which was based on the Framework Agreement between UNICE, CEEP, and ETUC, [1998] OJ L14/9; Directive 99/70 on fixed-term work [1999] OJ L175/43, which was based on the Framework Agreement between UNICE, CEEP, and ETUC [1999] OJ L175/43. Two Directives concerned the sectoral level: see Directive 99/63/EC on the organization of working time of seafarers [1999] OJ L167/33; Directive 2000/79/EC, on the organization of working time of mobile workers in civil aviation industry, [2000] OJ L302/57. For a detailed analysis, see Kenner, above n. 32, chap. 6. 
the content of the directives have been time-consuming ${ }^{172}$ and the whole process is relatively 'within closed doors'. Moreover, the number of directives adopted so far has been rather small. Finally, the content of the directives may be subject to criticism for the 'dilution of the quality of rights it recognises'. ${ }^{173}$

An important reason for the inclusion of the social partners is to increase the legitimacy without parliamentary democracy of the EU decision-making process in the context of social policy. ${ }^{174}$ This is probably the most controversial issue regarding the European Social Dialogue, which still ignites heated debate. ${ }^{175}$ This issue is strictly linked to the representativity of the European social partners, and it highlights the fact that the quasi-public function assigned to the latter is at odds with national collective bargaining, and more broadly with national IR systems. In fact it has entailed a loss of autonomy of the social partners, which historically has always typified their role in private contractual law. ${ }^{176}$ In this respect Bercusson has defined the inclusion of the social dialogue in the EU legislative procedure as 'bargaining in the shadow of the law'. ${ }^{177}$ Whereas in the national context 'the development of collective autonomy in a separate IR system, through autonomous rule-making procedures and judicial bodies, has always preceded heteronomous regulation in the supranational context supportive legislation has preceded the separate development of collective autonomy'. ${ }^{178}$

In the Communication on 'New Procedures Introduced by the Agreement on Social Policy and the Role of Management and Labour', 179 the Commission outlined the representativity criteria which needed to be met by the social

\footnotetext{
172 See C. Vigneau, K. Ahlberg, B. Bercusson, and N. Bruun (eds.), Fixed-Term Work in the EU. A European Agreement against Discrimination and Abuse (The National Institute for Working Life and the Swedish Trade Unions in Co-operation, Stockholm, 1999); Lo Faro, above n. 151, 115-21.

173 See Barnard, above n. 167, 94; see also Lo Faro, above n. 151, chap. 5. Particularly interesting is the distinction he introduces between 'tied agreements' and 'weak agreements' or 'inconsequential agreements'. Only the former type of agreement, which is implemented via a directive of the Council, has legal relevance in the EU, while the latter form of agreement, implemented 'in accordance with the procedures and practices specific to management and labour and the Member States', does not have any legal relevance at the Community level. Moreover, the implementation of the agreements by way of directives-with the agreements annexed separately to them-has raised a series of perplexities regarding the difficulty of maintaining intact the collective autonomy part of the agreement, especially with regard to the fact that a high margin of discretion is left to the Member States in the implementation of directives.

174 See B. Bercusson, European Labour Law (Butterworths, London, 1996) 72-8.

175 See Kenner, above n. 32, chap. 6.

176 See Lo Faro, above n. 165, 104-8, where the author criticizes the discretion with which the Commission assesses the outcome of the bargaining process, particularly the legality of the agreements, which is intended to examine whether the clauses of the agreements may be contrary to Community law. The author argues that the Commission has arrogated to itself the 'competence to perform a purely jurisdictional role', which pertains to the ECJ.

177 See B. Bercusson, 'Maastricht: A Fundamental Change in European Labour Law' (1992) 23 IRJ 3. More specifically, the 'shadow' of the Commission weighs on the whole social dialogue process. In this respect see Lo Faro, above n. 165.

178 See B. Caruso, 'Il Contratto Collettivo Europeo' (1997) II Lavoro, Impresa e Societá 322-33; see also S. Fredman, 'Social Law in the European Union: the Impact of the Lawmaking Process' in P. Craig and C. Harlow (eds.), Lawmaking in the European Union (Kluwer Law International, The Hague, London, Boston, 1998), 386, 408, and 410. $179 \operatorname{COM}(93) 600,14$ Dec. 1993.
} 
partners in the consultation process. ${ }^{180}$ Some commentators have argued that the Commission has distinguished 'with subtle and studied ambiguity' the social partners' consultative functions from their contractual relations functions by applying the above criteria only to the former. ${ }^{181}$ Currently, the ETUC, CEEP, and UNICE ${ }^{182}$ have a monopoly on the intersectoral social dialogue. ${ }^{183}$ The representativity, internal democracy, and accountability, i.e., the responsiveness of the social partners' hierarchy to their members, of these three major organizations have been contested due to their functional mode of operation and to the degree of membership and affiliation. ${ }^{184}$ These issues were raised in the UEAPME case. ${ }^{185}$ As Bercusson and Van Dijk posit, representativity is pivotal to establishing the identity of the social partners, ${ }^{186}$ and it is thus a key criterion in the admissibility test which the CFI makes. The salient parts of the judgment, which declared the action lodged by UEAPME inadmissible, were the following: ${ }^{187}$

- The consultation stage is different from the negotiation stage, and there is no general right for those consulted to take part in the negotiations under Articles 3(4) and $4 \mathrm{SPA}^{188}$ or an individual right to participate in negotiations of the framework agreement;

- The CFI emphasized the dual nature of EC labour law. In fact the CFI stated that in the context of the ASP, democratic legitimacy derives from Parliament's participation through the conventional legislative procedure under Article 2(2). ${ }^{189}$

180 The criteria for organizations to be eligible are the following: (a) organizations have to be cross-country or concern specific sectors or categories and be organized at European level; (b) organizations must consist of organizations which are themselves an integral and recognized part of Member State social partner structures; (c) organizations must have the capacity to negotiate agreements and be representative of all Member States as far as possible; and, (d) organizations must have adequate structures to ensure their effective participation in the consultation process. The list was confirmed by the Communication, Adapting and Promoting the Social Dialogue at Community Level, COM(98)322 final, 20 May 1998.

181 See B. Bercusson and J. Van Dijk, 'The Implementation of the Protocol and Agreement on Social Policy of the Treaty of the European Union' (1995) 11 IJCLIR 16.

182 ETUC, European Trade Union Confederation; UNICE, Union of Industrial and Employers; CEEP, European Centre of Enterprises of General Economic Interest.

183 See Barnard, above n. 167, 90.

184 See G. Britz and M. Schimdt, 'The Institutionalised Participation of Management and Labour in the Community Law' (2000) 6 ELJ 45; B. Keller and B. Sörries, 'The New Social Dialogue: Old Wine in New Bottles?' (1999) 9 JESP 110.

185 See Case T-135/96 UEAPME v. Council [1998] ECR II-2335. The case concerned a challenge to the legality of the Directive on parental leave by UEAPME, which claimed to represent the largest number of small and medium-sized employers (SMEs) at pan-European level. UEAPME's main contention was that since it had been involved in the first consultation procedure it should necessarily have been involved in the second consultation process, given the fact that the interests of SMEs were different from those of UNICE.

186 See Bercusson and Van Dijk, above n. 181, 12-13.

187 See B. Bercusson, 'Democratic Legitimacy and European Labour Law' (1999) 28 ILJ 153-71; see also L. Betten, 'The Democratic Deficit of Participatory Democracy in Community Social Policy' (1998) 23 EL Rev. 32; M. Schimdt, 'Representativity-A Claim Not Satisfied: The Social Partners' Role in the EC Law-Making Procedure for Social Policy’ (1999) 15 IJCLIR 262-3.

188 Now Arts. 138(4) and 139 EC. 189 Now Art. 137(2) EC. 
Under the procedure of Article 4(2) ${ }^{190}$ instead the EU Parliament is not called to participate. Democracy, which is a fundamental principle and a foundation for the Union under Article F(1) TEU, ${ }^{191}$ requires that the participation of the people be otherwise assured, in this case through the participation of management and labour in the legislative process. ${ }^{192}$ The Commission and the Council therefore have a duty to verify the representativity of the signatories to the agreement and to refuse to implement the agreement if they are found to be insufficiently representative;

- The Commission and the Council took sufficient account of the representativity of the parties to the agreement on parental leave. The CFI insisted that the 'collective representativity' of the parties has to be made in relation to the content of the agreement. Since the signatories were general inter-sectoral organizations with a general mandate they were sufficiently representative. The CFI also noted that the interests of SMEs were adequately represented by UNICE;

- On these grounds the CFI concluded that UEAPME did not have the required individual concern to bring proceedings under Article 173 EC. ${ }^{193}$

The ruling is subject to criticisms on many points. First, the CFI did not assess the validity of representativity criteria, but only whether they had been applied correctly. It also failed to take into account the representativeness issue with regard to those workers who are not members of trade unions. Secondly, it differentiated between the informal consultation stage and the formal negotiation stage to confirm its statement, and in doing so it implicitly endorsed the monopoly of the three major organizations. Thirdly, and linked to the former, the 'CFI has favoured a narrow representation-based model of democracy, which is concerned with the procedural rather than a wider participatory model that legitimates on the basis of the outcomes'. ${ }^{194}$ This entailed a strict approach to the rules on standing of private associations. Fourthly, it did not address the issue of ' who has legitimacy to negotiate and how to balance wider participation with effective negotiation'. ${ }^{195}$

\section{THE CONSTitutionalization OF NEW EU GOVERNANCE}

Now that both the EES and the European Social Dialogue have reached a period of consolidation abstract questions have become practical questions which cannot be avoided if 'new governance' is to be taken seriously. Although the Treaty of Amsterdam has provided a legal basis for the development of a uniform regulation of social policy at the European level clear implementation and enforcement procedures, which guarantee compliance, ${ }^{196}$ need to be

190 Now Art. 139(2) EC. 191 Now Art. 6(1) TEU.

192 See Bercusson, above n. 187, 164-5, The author criticizes the CFI equivalence of the EU Social Dialogue to the EU legislative process.

194 See Kenner, above n. 32, chap. 6. $\quad 195$ Ibid., 92.

196 In using the term compliance I refer to the broad definition of it given by Joerges and Vos. The authors describe compliance as including not only mere obedience to rules but also 'reflexive 
taken into consideration. An analogy may be drawn between this situation and Vervaele's metaphor that 'once the house is ready and house rules have been determined, it becomes more and more important that those rules are complied with and that the house will not be undermined by inferior upkeep or operations that endanger the structure'. ${ }^{197}$

As Szyszczak argues, it may well be that in the future the ECJ may be called on to address the legality of the various processes which take place within the EES, and that these rulings will shed light on the distribution of competence but, as she aptly points out, issues relating to locus standi and representativeness and consultation will, ceteris paribus, still remain unsolved at the European level. ${ }^{198}$ Finally, and linked to the former, the EPGs cover policy areas which directly affect individual rights. Although the guidelines have normative effects there is no possibility of challenging either their validity or the procedure with which they are adopted. ${ }^{199}$ Hence, issues regarding the protection of individual rights also need to be tackled.

My contention is that the current framework should be re-articulated, transposing the results obtained through the EES/OMC into hard law. It must be emphasized that although for some scholars this might appear to be one of the most impractical reforms and to others unnecessary, it is indeed necessary and particularly relevant. This would create a positive dialectical link between the two forms of law. The proposals for reform made in section $\mathrm{D}$ of this chapter do not entail a systematic review of the EU institutional framework in toto but the insertion of specific procedural rules and rights, which guarantee transparency, legal certainty, and the protection of substantive social rights. This becomes particularly compelling in view of the enlargement process where the accession countries present altogether different political patterns and social and economic situations.

Following the Barcelona European Council, which called for a strengthening of the EES, the Commission issued a series of Communications. In the Communication Taking Stock of Five Years of the European Employment Strategy the Commission reviewed the experience of five years of the EES and broadly outlined a re-design of the EES for the future. ${ }^{200}$ Ten topics were the subject of the evaluation:

Prevention and policies of activation to employment;

Tax reforms and benefits;

Lifelong learning;

Social inclusion;

Administrative simplification and the self-employed;

attitudes and a notion of co-operation; an appreciation of the distinction between command and control types of administrative practices; and a sensitivity to the difference between interpretation of a rule and its application to a real situation'. See C. Joerges and E. Vos, 'Structures of Transnational Governance and Their Legitimacy’ in Vervaele (ed.), above n. 15, 71.

197 See J. Vervaele, 'Transnational Cooperation of Enforcement Authorities in the Community Area' in Vervaele, above n. 15, 361.

198 See Szyszczak, above n. 27, 219.

199 Ibid., 218. 200 COM(2002)416 final. 
Creation of jobs in services, at local level, and in social economy;

Taxation;

Modernizing work organization;

Equal opportunities;

Changes in policy-making.

The Communication identified four main issues for the reform of the EES:

(a) the need to set clear objectives in response to the policy challenges;

(b) the need to simplify the policy guidelines without undermining their effectiveness;

(c) the need to improve governance and partnership in the execution of the strategy; and

(d) the need to ensure greater consistency and complementarity with respect to other relevant EU processes.

The Communication stimulated an active debate. In particular, the EU Parliament issued a resolution in which it suggested the adoption of various measures to strengthen the EES ${ }^{201}$ and the EMCO and the Economic Policy Committee reached a joint position that was submitted to the Council. ${ }^{202}$ The Commission further developed the objectives outlined in this Communication in a subsequent Communication on the future of the EES ${ }^{203}$ where it provided examples of concrete objectives and considerations and suggestions for possible new targets.

The Commission issued a Communication on streamlining EPGs and BEPGs $^{204}$ with a shift towards a more medium and longer-term approach in order to foster progress towards full employment, sustainable development, and, more broadly, for the advancing of the European social model. From a methodological perspective the aim of the new process is to improve coherence and complementarity between the various processes and instruments, foster the participation and involvement of the EU Parliament and the national Parliaments, a better consultation of social partners and civil society, and increase the transparency and intelligibility of the policy co-ordination. ${ }^{205}$

In line with the new and streamlined approach for the overall Lisbon agenda follow-up, the Commission presented a Guidelines Package in April 2003 which included formal proposals of BEPGs and EPGs, ${ }^{206}$ the annual

201 See European Parliament, Committee on Employment and Social Affairs, Report on the Communication from the Commission to the Council, the European Parliament, the Economic and Social Committee and the Committee of the Regions on Taking Stock of Five Years of the European Employment Strategy, PE 316.370 of 25 Sept. 2002.

202 See Joint Opinion of the Employment Committee and the Economic Policy Committee on the Future Direction of the European Employment Strategy, at: http://europa.eu.int/comm/ employment_social/employment_strategy/opinions2002_en.htm.

203 COM(2003)6 final.

204 See COM(2002) 487 final, 3-8; Communication from the Commission to the Council and the European Parliament, Strengthening the co-ordination of budgetary policies, COM(2002)668 final. 205 Ibid., 2.

206 For detailed information on the main implications of the proposed changes see $\operatorname{COM}(2002) 487$ final, Appendix 2. For an analysis of the new guidelines see Council Decision 
recommendations to the Member States covering a three-year period up to 2006. In particular, the guidelines are to be issued annually only if they have to stress the importance of possible major new developments. Likewise and consistently with the Cardiff process and pursuant to the Lisbon Strategy, the Internal Market Strategy, ${ }^{207}$ which accompanies the Guidelines Package, considers internal market matters until 2006 and will be subject to changes during this three-year period only if necessary. According to the new procedures after the June European Council has considered the current situation in the economic and social fields, the Council adopts the BEPGs, the EPGs, the Employment Recommendations to Member States, and/or adopts action plans in their areas of competence. The first full application of the proposed new arrangements for reviewing implementation took place in the autumn of 2003. As a transitional measure, however, the draft Joint Employment Report was adopted in the autumn of 2002, 208 instead of January 2003, as would follow from the general approach of the new overall process. ${ }^{209}$

What follows is a first set of Treaty reforms which aim at increasing the efficiency of the EU decision-making process and the effectiveness of EU law and which revolve around the democratic legitimacy-accountability-transparency nexus of the polity system of the European Union. I will then further develop these proposals into specific amendments to the Treaty provisions, in particular Titles VIII and XI. ${ }^{210}$ One caveat must be made. The problem of effectiveness of EU law cannot be solved by ad hoc remedies but requires the implementation of reforms regarding the whole structural and regulatory system of the European Union. My proposals should therefore be contextualized in the framework of the overall revision of the EC Treaty. A first set of amendments, which should go in tandem with a series of institutional and structural reforms, regards the systematization of the legal instruments of the European Union by way of establishing a hierarchy of acts. The European Convention has certainly contributed to this in the draft Constitutional Treaty. ${ }^{211}$ This

of 22 July 2003 on guidelines for the employment policies of the Member States [2003] OJ L197/13 and Council Recommendation of 22 July 2003 on the implementation of Member States' employment policies [2003] OJ L197/22.

207 The Internal Market Strategy has been given a 5-year time frame and its proposed actions are reviewed each year. In addition, the next phase of the Strategy has been linked to the Lisbon Strategy.

208 See Communication from the Commission to the Council, Draft Joint Employment Report 2002, COM(2002)621 final.

209 In Jan. 2003 the Commission presented the Report to the Spring European Council, 21 Mar. 2003, on the Lisbon Strategy economic, social, and environmental renewal. See Communication from the Commission, Choosing to Grow: Knowledge, Innovation and Jobs in a Cohesive Society, COM(2003)5 final.

210 In the draft Constitutional Treaty Titles VIII and XI have been renumbered Section I, 'Employment' and Section II, 'Social Policy', of Chapter III, 'Policies in other specific policy areas', of Title III, 'Policies and Internal Action', of Part III, 'The Policies and functioning of the Union'. See European Convention, Draft Treaty establishing a Constitution for Europe, CONV 820/1/03, REV 1, Brussels, 27 June 2003 (01.07).

211 See Part I, Title III on the Union's competences, Title V on the Exercise of Union competence, and Title VI on the Democratic Life of the Union of the Draft Constitutional Treaty. 
hierarchy should introduce a distinction between primary and secondary legislation, legislative and executive acts, and binding and non-binding legal instruments, ${ }^{212}$ and also define the scope of application of the EU legal instruments. Such a reform would simplify the EU decision-making process by introducing greater efficiency, transparency, and thus responsiveness and accountability. At the top of this hierarchy, primacy should be given to the Treaties, followed by a set of constitutional principles, including those principles established and developed by the European Court's case law which are now part of primary law and a code of fundamental rights. ${ }^{213}$

Secondly, there should be the regulation, the directive, and the decision. In particular, the directive should establish the aim, the obligations, and the conditions of the envisaged measure. Moreover, once a directive has been adopted and within a time agreed upon during a meeting of the Council, Member States should present reports stating how and when they intend to transpose the act into national law. This would not only guarantee legal economy but, most importantly, it would strengthen the principle of legal certainty and thus improve the legal protection offered to individuals. The Commission and ad hoc committees also at the national level should supervise the whole process of transposition into national law. The lower level of the hierarchy should include recommendation, opinion, guideline, Green and White Papers, action plan, agenda, declaration, resolution, and statement, which fall into the category of non-binding legal instruments.

In this respect, the hierarchy of acts should also clearly define the scope and the purpose of soft-law instruments, such as co-regulation, the Open Method of Co-ordination, and the use of benchmarks and self-regulatory codes of conduct. This would be facilitated by a strict definition of competencies. These instruments should be used only in those policy areas where there is no exclusive competence of the European Union or where there is a shared competence between the Community and the Member States. In this regard, it becomes necessary to amend Article $308 \mathrm{EC}$ in order to eliminate the ambiguity of the provision and to shed more light on when 'action by the Community should prove necessary' and when the 'Treaty has not provided the necessary powers'. The amended provision could list a series of concrete circumstances in which Community action might be needed, rather than simply stating 'during the course of the operation of the common market'. Secondly and related to the former, Article 5 EC should be reviewed in the light of the new developments and pursuant to the idea of allocative efficiency, ${ }^{214}$ which the principle

See European Convention, Draft Treaty establishing a Constitution for Europe, CONV 820/1/03, REV 1, Brussels, 27 June 2003 (01.07).

212 For a similar view, see S. Sciarra, 'Social Values and the Multiple Sources of European Social Law' (1995) 1 ELJ 81. Sciarra argues that 'There is also a need to put rules in their place and to have a clear idea of sources and of their legal nature. This imperative must be appreciated in view of a better understanding and enforcement of European sources in each national system, which is also one of the aims specified in the Maastricht Treaty'.

213 The EU Charter of Fundamentals Rights constitutes Part II of the draft Constitutional Treaty. See European Convention, Draft Treaty establishing a Constitution for Europe, CONV 820/1/03, REV 1, Brussels, 27 June 2003 (01.07). 214 See also Kenner, above n. 32, chap. 6. 
of subsidiarity has been subject to over the years. The Protocol attached to the Amsterdam Treaty in fact allows for a broader interpretation of subsidiarity: 'subsidiarity is a dynamic concept and should be applied in the light of the objectives set out in the Treaty. It allows Community action within the limits of its powers to be expanded where circumstances so require.' ${ }^{215}$ Furthermore, the distinction between horizontal and vertical subsidiarity, which has been defined in academia, should be included in the provision that refers only to the distribution of competence between the Member States and the Community. ${ }^{216}$

The inclusion of the horizontal element of subsidiarity takes into consideration the new multi-tiered structure of the EU policy-making process. The amended provision should include in paragraph 2: 'only if and insofar as the objectives of the proposed action cannot be sufficiently achieved by the Member States, by the regional, local authorities or by organised civil society'. A reviewed Protocol on the principle of subsidiarity should define what is meant by 'regional', 'local' authorities, and 'civil society' and establish a criterion for determining when to apply the revised principle of subsidiarity.

Thus these soft-law instruments should be applied to those policy areas where consensus is difficult to achieve owing to historical, political, social, and cultural differences between the Member States, and where harmonization of policy at the EU level is explicitly excluded. Such has been the case in the context of the economic co-ordination of the Economic and Monetary Union (EMU), in the field of social policy sensu lato, ${ }^{217}$ in environmental policy with the 'Sustainable Development Strategy', 218 and, more recently, in the area of asylum and immigration policy. ${ }^{219}$ A clear distribution of competencies is a precondition for an adequate definition of those policy areas where soft-law instruments may be used.

Soft-law is often the precursor of subsequent legally binding decisions. It 'smoothly' introduces changes at the national level. It creates an expectation that conduct of the European Union, Member States, and individuals will be in conformity with the non-binding rule. More precisely, 'during the process of creation of hard law, soft-law can have a legitimising prohibitive

215 See European Council, 'Protocol on the application of the principles of subsidiarity and proportionality', annexed to the Treaty of Amsterdam amending the Treaty on European Union, the Treaties establishing the European Communities and certain related acts [1997] OJ C340/1. See also Kenner, above n. 32, chap. 6, who argues that subsidiarity is a natural by-product of the expansion of the Community's competencies. As the Community's reach expands, subsidiarity operates as a process for managing interdependence between sub-national, national, and supranational actors.

216 In this respect, the principle of horizontal subsidiarity should be given a broad meaning in order to include the principle of proximity, which refers to forms of participatory democracy. See Art. I-9(3) of the Constitutional Treaty, European Convention, Draft Treaty establishing a Constitution for Europe, CONV 850/03, Brussels, 18 July 2003.

217 See, above, section 1 of this chap.

218 The 'Sustainable Development Strategy' is considered in the follow-up to the Lisbon Strategy with the further inclusion of a third environmental dimension to it. See Presidency Conclusions of the Göteborg European Council, 15 and 16 June 2001, para. 20; see also Presidency Conclusions of the Stockholm European Council, 24 Mar. 2001, paras. 50-52.

219 See Communication from the Commission to the Council and the European Parliament on the Common asylum policy, introducing an open co-ordination method COM(2001)710 final, 28 Nov. 2001. 
or prescriptive effect on state conduct before the phase of legality is reached. The temporal element will play an important role in this regard.'220

A way of introducing a means of redress for the individual and private parties, which would help to overcome the lack of legal sanctions in the pre-hardlaw stage, could be by way of Article 234 EC, i.e., preliminary ruling. In the Grimaldi case $^{221}$ the Court stated that according to its interpretation of Article 177(1)(b) EC, the term 'acts' also includes non-binding recommendations and opinions mentioned in Article 249 EC. More precisely, the Court said that although non-binding legal instruments cannot have direct effect on national courts, a national court or a tribunal is competent to refer to the Court a question concerning their interpretation or validity. Such a reference may be appropriate where the recommendation or opinion fostered the adoption of a particular provision of national law relevant to the case before the national court or tribunal or because a recommendation or opinion casts light on the interpretation of other provisions of Community law that are binding and relevant to the case under consideration. Hence, a solution could be to challenge a national measure adopted pursuant to a non-binding legal instrument in domestic courts, which could refer a question to the European Court concerning the interpretation or validity of a non-binding EU act. This would allow indirect challenge to non-binding Community acts and thus help to overcome the problem of the restrictive standing rules of Article 230 EC. In analysing the ruling in the Grimaldi case, Klabbers posits that 'if legally nonbinding provisions supplementing binding provisions must be taken into account, it follows that, the language of Article 189 EC notwithstanding, those legally non-binding provisions must for all practical purposes be treated as legally binding. Similarly, it would seem that in situations where only applicable Community provisions are cast in the form of recommendations (as was the case in Grimaldi), those recommendations must for all intents and purposes be treated as legally binding.' ${ }^{222}$ Klabbers refers to the final sentences of the ruling, where the Court says that national courts are bound to take recommendations into consideration 'where they are designed to supplement binding Community provisions'. ${ }^{223}$ If the Court followed Klabbers' argument in its case law it would certainly increase the judicial remedy for EU acts. Finally, the accountable and transparent functioning of the EU institutions could be improved by introducing a better system of publicity of the acts adopted, on the modalities and procedures followed in their adoption and by

\footnotetext{
220 See K.C. Wellens and G.M. Borchardt, 'Soft Law in European Community Law' (1989) 14 EL Rev. 314. See Kenner, above n. 32, chap. 6, who argues that 'subsidiarity has guided the exercise of power at Community level by creating a presumption that national measures are to preferred and, even in areas where the legal bases for Community measures have been expanded, programmatic activity or soft law should be considered as a first step'.

${ }_{221}$ See Case C-322/88 Grimaldi v. Fonds des Maladie professionelles [1989] ECR 4407.

222 See J. Klabbers, 'Informal Instruments Before the European Court of Justice' (1994) 31 CML Rev. 1014 (emphasis added).

${ }^{223}$ See Case C-322/88 Grimaldi v. Fonds des Maladie professionelles [1989] ECR 4421 (emphasis added).
} 
increasing the number of accessible EC documents. More transparency would consequently guarantee more accountability since it could be possible to know who does what.

\section{THE EUROPEAN EMPLOYMENT STRATEGY AND THE ACQUIS COMMUNAUTAIRE OF EC LABOUR LAW}

The issues examined in the previous sections lead the analysis to an important topic: the birth of a collective body of non-binding legal instruments and how to incorporate them in the discourse of hard-law instruments.

My contention is that it is necessary to create an institutional framework in the context of EU social policy where, according to the (revised) principle of subsidiarity, there is a clear distribution of competence among the relevant actors whose tasks and functions are accurately defined. This institutional framework would have the advantage of eliminating situations of uncertainty or any forms of institutional opacity. ${ }^{224}$ It would thus increase legitimacy, transparency, and guarantee legal certainty. ${ }^{225}$ Most of the members of Working Group VI on Economic Governance of the European Convention were in favour of including the basic objectives, procedures, and limits of the OMC in the Constitutional Treaty in a way which would not undermine the flexibility of the method and which would not have the effect of replacing or circumventing the Community method. In addition they suggested widening the consultation process, particularly with the social partners. ${ }^{226}$ Some members of Working Group XI on Social Europe of the European Convention suggested inserting a horizontal provision into the EC Treaty defining the OMC and its procedure, and specifying that the method can be applied only where no Union legislative competence is enshrined in the Treaty and in areas other than those where the co-ordination of national policies is governed by a special provision of the Treaty defining such co-ordination, i.e., Articles 99, 104, and $128 \mathrm{EC}$ or where the EU institutions have competence only for defining

224 See D. Hodson and I. Maher, 'The Open Method as a New Mode of Governance: the Case of Soft Law Economic Policy Co-ordination' (2001) 39 JCMS 730-2.

225 The systematization of recent developments in the area of soft law has also been posited by many academics. See, among others, C. Degryse and P. Pochet, 'The Likely Impact of the IGC on European Social Policy', IGC Info, Observatoire social européen electronic newsletter on the Intergovernmental Conference, 3 Nov. 2000, available online at: www.ose.be/; J. Goetschy, 'The Future of the European Employment Strategy' in U. Mückenberger et al. (eds.), Manifesto Social Europe (ETUI, Brussels, 2001); Szyszczak, above n. 32, 1139; Szyszczak, above n. 27, 203-4; Sciarra, above n. 212, 60; N. Bruun, 'The European Employment Strategy and the 'Acquis Communautaire' of Labour Law' (2001) 17 IJCLIR 324; B. Bercusson, 'The European Employment Strategy and the EC Institutional Structure of Social and Labour Law', paper presented at the SALTSA Workshop, 'Legal Dimensions of the European Employment Strategy' Brussels, 9-10 Oct. 2000, 16-18; on a comprehensive provision for collective labour law see European Parliament Committee on Employment and Social Affairs, Report on Trans-national Trade Union, 20 Mar. 1998 (A4-0095/98), ETUC, A Legal Framework for European Industrial Relations (1999), available online at: www.etuc.org.

226 See European Convention, Final Report of Working Group VI on Economic Governance, CONV 357/02, WG VI 17, Brussels, 21 Oct. 2002, 5. 
minimum rules. ${ }^{227}$ In addition, the Working Group suggested that the Treaty provision should have been incorporated into the Constitutional Treaty, within the Chapter on the EU instruments which contains non-legislative measures. The provision would then have defined the objectives and the basic elements of the OMC, i.e., the identification of common targets, outcome indicators, the establishment of a timetable for action, and the promotion of the exchange of best practices. ${ }^{228}$ The Group also recommended introducing some procedural rules regarding OMC implementation. In particular, the OMC would be used each time following a decision of the Council on the basis of a Commission proposal with the notification of the EU Parliament and the consultation of national parliaments, regional and local authorities, social partners, and civil society.229 Moreover, the Committee on Employment and Social Affairs of the European Parliament has proposed that the EES/OMC should be integrated with the national policy-making procedure, and in particular that NAPs should be adopted by the national parliament concerned on the basis of a government bill. ${ }^{230}$

This new institutional framework is also important from an economics perspective. In fact, 'deeper economic integration will in addition mean that market failures whose correction requires collective action and enforcement, will pose problems where the collective action and enforcement are national but the markets are European.' ${ }^{231}$ One set of ideas for the creation of this new institutional framework is to amend some of the provisions contained in Title VIII regarding the Employment Strategy and Title XI on the European Social Dialogue.

The difficulty in creating a new institutional framework is due to the intrinsic difference between Titles VIII and XI. In fact, whereas Title VIII is a 'vertical consolidation' of a number of years of political thinking initiated by the Commission and often endorsed by the Member States through soft law measures, Title XI on the contrary represents a 'horizontal consolidation' of accepted judicial and political practice, ${ }^{232}$ and it illustrates the structural dichotomy between sensitive and non-sensitive areas of Community intervention in EC social policy. ${ }^{233}$

As Szyszczak argues, the strict interrelationship between soft and hard law would guarantee the 'rule of law' approach, ${ }^{234}$ i.e., proper consultation,

227 See European Convention, Final Report of Working Group XI on Social Europe, Brussels, 30 Jan. 2003, CONV 516/03, WG XI 9, paras. 41-3. 228 Ibid., para. 42. 229 Ibid., para. 45.

230 See European Parliament, Committee on Employment and Social Affairs, Working Document on the impact evaluation and future of the European Employment StrategyOverview of technical analysis, DT $\backslash 463273 E N . d o c$.

231 See I. Begg, 'EMU and EMPLOYMENT. Social models in the EMU: Convergence? Co-existence? The Role of Economic and Social Actors', 5, 'One Europe or Several?' Working Paper 42/02, available online at: www.sbu.ac.uk/euroinst/oneeurope/papers.html.

232 See Szyszczak, above n. 27, 197; see also E. Szyszczak, 'The New Parameters of European Labour Law' in D. O'Keeffe and P. Twomey (eds.), The Treaty of Amsterdam (Hart Publishing, Oxford, 1999).

233 See Szyszczak, above n. 27, 203.

${ }^{234}$ See Case 294/83 Parti Ecologiste Les Verts v. European Parliament [1986] ECR 1339, where the Court stated that the Community is a legal order based upon the rule of law. 
transparency, and proper legal processes in creating legislation. ${ }^{235}$ Such legislation would be subject to scrutiny and create legal rights that could be enforceable in national legal systems through the principles of direct and indirect effect and state liability. ${ }^{236}$

The EES must also be understood against the background of EMU. As Begg argues, 'the advent of monetary union reinforces the case for the EU level to play a more extensive role in employment policy, particularly in developing an over-arching framework within which local actors can deal with employment problems'. ${ }^{237}$ In particular, increasing the free movement of goods, capital, and labour reduces the legal restrictions for economic actors. ${ }^{238}$ National public expenditure to finance social security systems could be ineffective because of labour and capital mobility. ${ }^{239}$ Hence there is the need to find common strategies, which need to be implemented in the long term through legally binding instruments.

Some first attempts to link the European Employment Strategy to EC labour law have already been made since the Treaty of Amsterdam. ${ }^{240}$

In the Preamble to the European Framework Agreement on Part-time Work, which led to the adoption of Council Directive 97/81/EC, the European social partners stated that:

This framework agreement is a contribution to the overall European strategy on employment. ${ }^{241}$ Part-time work has had an important impact on employment in recent years. For this reason, the parties to this agreement have given priority attention to this form of work. It is the intention of the parties to consider the need for similar agreements relating to other forms of work.

In the Preamble to the Framework Agreement on Fixed-term Work concluded by the European social partners, which led to Council Directive 1999/70/EC, it is stated:

This framework agreement illustrates the role that the social partners can play in the European employment strategy agreed at the 1997 Luxembourg extraordinary sum$m_{i t^{242}}$ and, following the framework agreement on part-time work, represents a further contribution towards achieving a better balance between 'flexibility' in working time and security of workers.

The Preamble to the Council Directive emphasizes the relevance of the Employment Strategy, which states the following in paragraph 6:

The Council Resolution of 9 February 1999 on the 1999 Employment Guidelines invites the social partners at all appropriate levels to negotiate agreements to modernise the organization of work, including flexible working arrangements, with the aim of making undertakings productive and competitive and achieving the required balance between flexibility and security.

\footnotetext{
235 See Szyszczak, above n. 27, $203 . \quad 236$ Ibid., 203-4. $\quad 237$ See Begg, above n. 231, 4.

238 Ibid. 239 Ibid.

240 See Bruun, above n. 225, who exhaustively illustrates and explains the relationship between the EES and EC labour law. Some of the examples are taken from the author's article.

241 Emphasis added. 242 Ibid.
} 
Moreover, in the Fixed-term Directive 99/70/EC there are also some provisions that take into consideration the Employment Strategy. Paragraph 2 of clause 6 prescribes that, as far as possible, employers should facilitate access by fixed-term workers to appropriate training courses in order to improve their skills, career development, and occupational mobility. In this clause there is an implicit reference to the then 'Employability' pillar of the EPGs.

The framework agreements and directives mentioned are particularly relevant with regard to policies of the then 'Adaptability' pillar of the EPGs, where the social partners have a pivotal role in the modernization of work organization and in guaranteeing a proper balance between flexibility and security.

More recently, the new Directive 2000/43/EC on race and ethnic discrimination directly refers to the Employment Strategy as a valuable policy tool in the promotion of minority groups in the labour market. The Preamble to the Directive refers in fact to the EPGs for the year 2000:243

The 2000 Employment Policy Guidelines agreed by the European Council in Helsinki, on 10 and 11 December 1999, stress the need to foster conditions for a socially inclusive labour market by formulating a coherent set of policies aimed at combating discrimination against groups such as ethnic minorities.

Directive 2000/78/EC, which establishes a general framework for equal treatment in employment and occupation, has a direct link to the Employment Strategy. In its recital it states: ${ }^{244}$

The EC Treaty includes among its objectives the promotion of coordination between employment policies of the Member States. To this end, a new employment chapter was incorporated in the EC Treaty as a means of developing a coordinated European strategy for employment to promote a skilled, trained and adaptable workforce. The Employment Guidelines for 2000 agreed by the European Council at Helsinki on 10 and 11 December 1999 stress the need to foster a labour market favourable to social integration by formulating a coherent set of policies aimed at combating discrimination against groups such as persons with disability. They also emphasise the need to pay particular attention to supporting older workers, in order to increase participation in the labour force.

Paragraph 1 of Article 6 provides the following:

1. Notwithstanding Article 2(2) Member States may provide that differences of treatment on grounds of age shall not constitute discrimination, if, within the context of national law, they are objectively and reasonably justified by a legitimate aim, including legitimate employment policy, labour market and vocational training objectives, and if the means of achieving that aim are appropriate and necessary.

The reference to the Employment Strategy is made explicit in paragraph 25 of the Preamble:

The prohibition of age discrimination is an essential part of meeting the aims set out in the Employment Guidelines and encouraging diversity in the workforce. However, differences in treatment in connection with age may be justified under certain circumstances and therefore require specific provisions, which may vary in accordance with the

243 See recitals 8-9. 244 Ibid., 7-8. 
situation in Member States. It is therefore essential to distinguish between differences in treatment which are justified, in particular by legitimate employment policy, labour market and vocational training objectives, and discrimination which must be prohibited.

Finally, Directive 96/34/EC on Parental Leave implicitly refers to the then 'Equal Opportunities' pillar of the EPGs. In the Preamble to the Directive in fact it states that the purpose of the Directive is to reconcile work and family life and to promote equal opportunities and treatment between women and men, which are all objectives of the then fourth pillar of the EPGs.

The study of the above framework agreements and directives shows that the soft implementation of the Employment Strategy and EC labour (hard) law are reciprocally influenced and reinforce the protection of the rights recognized in the directives. This dialectical relationship creates a solid-based EC social policy framework.

In addition, the above analysis shows that the boundary between soft law and hard law is not as clear-cut as it might seem. The inclusion of sensitive policy areas in the Community agenda in fact may be seen as a developing process, which can be subdivided into two phases. In the initial phase, softlaw instruments are preferable to hard law owing to the fact that these have been areas where there has traditionally been a very narrow margin of opportunity for action at the European level or which have never been in the remit of Community decision-making. More specifically, non-binding legal instruments, as the term 'soft' illustrates, are a useful tool to 'smooth' Member States that are often reluctant to devolve completely or partially the competence of certain policy areas. It thus allows for the organization of activities at the European level in sensitive policy areas such as employment, social inclusion, and social protection. In the second phase, i.e., once the policy areas have definitely reached the Community agenda, hard-law instruments become preferable and, therefore, the non-binding legal acts concerning a specific policy area should be transposed into binding instruments. Directives appear to be the most appropriate hard-law instruments because they leave a wide margin of discretion to the Member States. ${ }^{245}$ It would therefore allow them to introduce reforms in their national legislation according to their different welfare state and industrial relations systems.

What follows is a series of proposed amendments to Titles VIII and XI of the EC Treaty. In respect of Title VIII Article 128 EC should be amended in order to include both European and national social partners. With regard to the European social partners, Article 128(2) EC should be linked to Article 138(2) and (3) EC. ${ }^{246}$

245 See Goetschy, above n. 225, who endorses the view that directives would be the most suitable legal acts to associate the Employment Strategy with the Community Method.

${ }^{246}$ Art. 138(2) and (3) EC provides that: 'To this end, before submitting proposals in the social policy field, the Commission shall consult management and labour on the possible direction of Community action. If, after such consultation, the Commission considers Community action advisable, it shall consult management and labour on the content of the envisaged proposal. Management and labour shall forward to the Commission an opinion or, where appropriate, a recommendation'. 
Secondly, Article 128(2) EC should also be amended in order to enhance the role of the EU Parliament, the Economic and Social Committee, and the Committee of the Regions in the adoption of the EPGs. Thus, the legislative procedure regarding the adoption of the EPGs should be changed so that the EU Parliament, rather than being consulted by the Council, should act together with the Council in the adoption of the guidelines for employment. The legislative route to be used would be the co-decision procedure, pursuant to Article 251 EC. Within this context amendments should be made to the last sentence of paragraph 2 in order to eliminate the implicit subjection of the EPGs to the BEPGs.

Thirdly, Article 128(3) EC should be reviewed to include the participation of the social partners in the elaboration and implementation of the NAPs at the national level and to include the concertation between European, national, sectoral, and enterprise social partners.

Fourthly, Article 128(4) EC should be amended in order to include the EU Parliament, the Economic and Social Committee, and the Committee of the Regions.

The new provision in Article 128(2) EC would be as follows:

The Council acting with the procedure referred to in Article 251, and after consulting the Economic and Social Committee and the Committee of the Regions and the Employment Committee, and on a proposal from the Commission according to Article 138(2) and (3) EC, shall each year draw up guidelines, which Member States shall take into account in their employment policies. These guidelines shall be adopted in accordance with the objectives of the broad guidelines adopted pursuant to Article 99(2) EC. To this end, the Spring European Council shall assess the implementation of both guidelines, which are devoted to an overall social and economic strategy.

The new version of Article 128(3) EC would be as follows:

Each Member State shall provide the Council and the Commission with an annual report on the principle measures taken, in consultation with management and labour, to implement its employment policy in the light of the guidelines for employment as referred to in paragraph 2. The European social partners shall provide the Council and the Commission with a synthesis report on the principle measures taken, in concertation with the national, sectoral and enterprise social partners.

The new version of Article 128(4) EC would be as follows:

The Council, on the basis of the reports referred to in paragraph 3 and having received the views of the Economic and Social Committee, the Committee of the Regions and the Employment Committee, shall each year carry out an examination of the implementation of the employment policies of the Member States in the light of the guidelines for employment. The Council, acting by a qualified majority on a recommendation from the Commission and after consulting the Parliament, may, if it considers it appropriate in the light of the examination, make recommendations to Member States.

The EPGs should be amended in order to strengthen partnership on the basis of the principle of proximity and establish an integrated approach to tackle 
social issues. ${ }^{247}$ This could be achieved by strengthening the role of the social partners at all levels, but also by including the local and regional authorities and NGOs in creating a link between the NAPs and regional (RAPs) and local action plans (LAPs), which are emerging in some Member States. ${ }^{248}$ Moreover, the EES should be linked to other Community-level initiatives such as the 'Territorial Employment Pacts' (TEPs), launched as pilot projects in 1997,249 and URBAN. ${ }^{250}$ Furthermore, the new regulations governing the Structural Funds for the 2000-6 period support the EES in the local and regional dimension of the implementation of the Fund. ${ }^{251}$ The new ESF Regulation contains a specific provision aimed at facilitating the participation of local partners and NGOs in the ESF and supported programmes in the form of small grant schemes. ${ }^{252}$

Finally, with regard to the implementation of the NAPs, the meetings between the representatives of the governments of the Member States and officials of the Commission on the exchange of best practices and aimed at providing feedback on the implementation of the EPGs should include representatives of management and labour. These meetings should also be given a formal format and the minutes of the meetings should be made public. In this regard a new Annex to the EPGs could provide a set of procedural rules on the organization of these meetings.

The inclusion of different levels of social partners, the EU Parliament, the Economic and Social Committee, and the Committee of the Regions, regional and local authorities, and NGOs with the insertion of clearer procedural rules reinforces the effectiveness of the Employment Strategy by increasing the transparency of the process and representative and participatory forms of democracy to the whole strategy.

Two issues still remain to be addressed: the lack of legal sanctions and the protection of social rights, which are implicitly recognized in the EES. The

247 In particular G 6 (combating emerging bottlenecks); G 13, G 14 (modernization of work organization); G 15 (Lifelong Learning); G 17 (equal opportunities) G 18 (reconcile work and family life), and Horizontal Objective B (Quality of Work); C (Lifelong Learning Strategy); D (partnership); and F (common structural indicators). In the 2003 EPGs there is a reference to the involvement of parliamentary bodies, social partners, and other relevant actors. See Council Decision of 22 July 2003 on guidelines for the employment policies of the Member States [2003] OJ L197/21.

248 RAPs have been adopted in Finland, Portugal, and the UK, whereas LAPs have been adopted in Greece, France, Ireland, and Sweden. See Communication from the Commission to the Council, the European Parliament, the Economic and Social Committee, and the Committee of the Regions on 'Strengthening the local dimension of the European Employment Strategy', $\operatorname{COM}(2001) 629$ final, 6.

249 For information on the territorial pacts, see the Commission website, URL: http://inforegio. cec.eu.int/pacts. 250 See COM(2001)629 final, 10.

${ }^{251}$ See Communication on European Social Fund support for the EES, COM(2001)16 final/2, 23 Jan. 2001.

252 Art. 4(2) of Regulation (EC) 1784/1999 of the European Parliament and of the Council on the European Social Fund [1999] OJ L213/5 provides that Member States will allocate a reasonable amount of Objectives 1 and 3 appropriations for global grants, managed by intermediary bodies that will in turn support in the form of small grants the NGOs and local partnerships. 
participation of new grassroots associations and regional and local authorities, with a clear set of procedural rules and rights, partially overcomes the lack of legal sanctions. Even though some commentators may argue that this would add further complexity to the Strategy, the increase of transparency and, at the same time, the elimination of elitism introduce forms of direct accountability and responsiveness of the measures and acts adopted. With regard to the protection of social rights, which will be analysed in more detail in the next section, one way would be, in line with Klabbers' theory, ${ }^{253}$ to have recourse to a preliminary ruling. A second and more effective solution would be further to the amendments to Titles VIII and XI and in light of the EU Charter of Fundamental Rights, to facilitate the standing of individuals, private associations, namely trade associations and work councils, and public interest groups to bring actions for annulment under Article 230(4) EC.

With regard to Title XI the proposals for reform are made taking into consideration the fact that the social partners were included in the legislative process as a regulatory tool that, it was hoped, would enhance democracy. At the time of their inclusion, in the early 1990s, the main objective was to eliminate the legislative sclerosis in which the European Union found itself and to find valid solutions to fight against the high levels of unemployment and the social problems which it entailed. The social partners were, therefore, called to co-operate with the other EU institutions in the EU decision-making process. The quasi-institutional role assigned to them entailed a loss of their autonomy, which they typically have in the context of national IR systems. Their inclusion must therefore be contextualized in the framework of the 'humanization' process, which the EU institutions and particularly the Santer Commission had initiated to promote the creation of a European Social Area. Thus, the European Social Dialogue is to be distinguished not only from the conventional legislative process in which the EU Parliament has a formal role, but also from the traditional form of collective bargaining that takes place at the national level. This explains why it was only when UEAPME challenged the validity of the Parental Leave Directive that all the complex issues relating to the European Social Dialogue abruptly arose. It also highlighted the restrictions imposed on the exercise of standing of private associations before the European Courts.

The difficulty in overcoming this state of affairs is further increased by the fact that any changes made may lead either to a strengthening of the Community's competence in the area of social policy, which would undermine the principles of proximity and subsidiarity, or, on the contrary, to a real decision-making power of the social partners. This latter solution, however, would find opposition from many Member States. Furthermore, the difficulty is also to guarantee the respect of diversity whilst pursuing the Europeanization process.

This, however, is not the end of the story. Globalization and the shift towards bottom-to-top and transnational forms of regulation have also called 
into play new actors, namely regional and local authorities and organized forms of civil society, which are considered to be closer to the citizens and thus, as grassroots organizations, considered better to represent the interests and the needs of EU citizens.

The proposals for reform, therefore, do not attempt the full development of the issues outlined above, but rather suggest some amendments, which may help overcome the legal conundrum that the European Social Dialogue poses to the traditional understanding of social policy.

A first set of proposals concerns the representativity of management and labour, the role of the EU Parliament, and the better involvement of the social partners at the European, national, sectoral, and company levels. A second set of propositions focuses on the status of collective agreements made pursuant to Article 139 EC and their validity erga omnes. A third set of proposals concerns the incentive measures under Article 129 EC and Articles 136, 137, and 140 EC.

First, the representativity criteria listed in the Communication on New Procedures Introduced by the Agreement on Social Policy and the Role of Management and Labour ${ }^{254}$ should not only be amended in order to include other social partners, e.g., sectoral and enterprise level, but they should also be extended to the negotiation stage. In addition, they should be included in a binding legal document, which could be a decision as envisaged in Article 249 EC. This latter amendment would in fact allow the representatitivity criteria to be challenged before the European Courts.

Secondly, Articles 136-139 EC should be amended, in line with the revised representativity criteria, in order to include a broader spectrum of social partners.

Thirdly, Article 139 EC should be amended in order to include the EU Parliament together with the Council in the implementation of the collective agreements. The legislative procedure to be applied would be the one envisaged in Article 251 EC.

Fourthly, a new paragraph could be added to Article 139 EC, which would define the legal status of the two types of collective agreements, and in particular their erga omnes validity. This is particularly relevant since the erga omnes validity rule is not applied in all the Member States. Linked to the former, the provision should also specify the legal nature of the 'decision' of the Council, which is not envisaged in the sense of Article $249 \mathrm{EC}$ but has been interpreted to mean any legally binding act.255 This is at odds with the Council power either to amend ${ }^{256}$ or reject an agreement. ${ }^{257}$

Finally, as Bercusson aptly argues, ${ }^{258}$ the policy objectives prescribed in Articles 136, 137, and 140 EC could be covered by the incentive measures

254 COM(93)600, 14 Dec. 1993. The Communication, Adapting and Promoting the Social Dialogue at Community Level, COM(98)322 final, 20 May 1998, confirmed the list outlined in the previous Communication.

255 See A. Adinolfi, 'Admissibility of Action for Annulment by Social Partners and "Sufficient Representativity” of European Agreements' (2000) 25 EL Rev. 171.

256 Pursuant to Art. 250 EC. 257 In accordance with Art. 202 EC.

258 See Bercusson, above n. 225, 12. 
envisaged in Article 129 EC. This last amendment is particularly relevant as it highlights the common objectives of the two Titles and thus strengthens my contention of establishing a new framework by way of linking the two Titles together.

The Report of the High Level Group on 'Industrial Relations and Change in the European Union' 259 in fact highlights the need to create a link between the policy objectives under Titles VIII and XI and also the importance of broadening the spectrum of social partners involved in the Employment Strategy and European Social Dialogue. It maintains that: 'a new agenda for industrial relations should be developed at all levels in order to cope with some key priorities' and 'build on already emerging new practices'. ${ }^{260}$ The High Level Group 'acknowledging the diversity of national patterns of industrial relations, identifies some main trends: the renewal of sectoral bargaining, the decentralization at enterprise level and local level and the role of national pacts to deal with strategic issues. The relationship between social dialogue and civil dialogue is also highlighted.' ${ }^{261}$ The new agenda is also important with regard to the structural adaptation in the accession countries. ${ }^{262}$

Most importantly, the High Level Group suggests developing a benchmarking process for industrial relations and an open method of co-ordination by the social partners as a new action tool with the support of the newly created European Monitoring Centre on Change (EMCC). ${ }^{263}$ The social partners are in fact uniquely suited to the strengthening of social policy because of their knowledge of the factual basis of various social and employment and labour market issues. ${ }^{264}$ The High Level Group also stated that industrial relations can make an important contribution to 'good governance' 265 promoting the implementation of the Lisbon Strategy and fostering modernization based on a new social contract, which includes, inter alia, national pacts, European Works Councils, and the European sectoral social dialogue. The High Level Group outlines the way the new agenda promotes good governance in the new multilevel framework where the industrial relations actors are developing a new multi-level system for conducting their own affairs. This is by establishing:266

a relationship between the different levels (European, national, local, enterprise), taking into account the distinction between sectoral and cross-industry industrial relations;

259 See European Commission, Employment and Social Affairs, Manuscript, Brussels, Unit EMPL/D.1, Jan. 2002.

260 Ibid., 5. The key priorities are: competitiveness and innovation with social cohesion, wage responsiveness, social inclusion, and social protection, training, and life-long learning, working conditions and work organization, new forms of employment, working time management, reconciliation of work and family life.

261 Ibid. See also 29-30, where the relationship between social and civil dialogue is emphasized in order to address new issues and problems, which have emerged more recently.

${ }^{262}$ Ibid., 32-3; 41-2. $\quad{ }^{263}$ Ibid., 6-7; 34-41. $\quad{ }^{264}$ See Fredman, above n. 178, 410.

265 The High Level Group defines it as 'the way society organises and rules itself in order to make and to implement choices'. See High Level Group Report, above n. 259, 24.

266 Ibid., 24 and 32. 
a relationship between bipartite and tripartite processes;

a relationship between different procedures (consultation, concertation, collective bargaining, etc.) and instruments (agreements, guidelines, etc.)

In this context the European Works Councils (EWCs) play an important role as they represent 'networks of employees' representatives across borders, where local representatives are likely to meet on a regular basis'. This provides a basis for dialogue and co-ordination of bargaining. ${ }^{267}$

An important distinction made in the Report is between social dialogue and collective bargaining, the former being 'a process, in which the actors inform each other of their intentions and capacities, elaborate information provided to them, and clarify and explain their assumptions and expectations'. Collective bargaining instead is 'a rule-making process based on joint decision-making between independent organizations (firms, employers associations, unions or union federations) with partly overlapping membership'. More precisely, 'it is an important regulatory institution of employment relations, of determining wages, working hours and the employment conditions of workers. Through their joint authorship of the rules, negotiating parties accept joint responsibility for the implementation and renewal of rules.' The High Level Group argues that collective bargaining can function better in the context of social dialogue. ${ }^{268}$

The High Level Group also proposes to introduce a dialectical and political dialogue between the European social partners and the Council on a more regular basis. This would provide an additional incentive for national social partners actively to participate in European social dialogue. ${ }^{269}$

Finally, the High Level Group invites the social partners to put forward proposals for reform, including proposals to modify the Treaty. ${ }^{270}$

The proposals for reform put forward by the High Level Group represent a valid response to the criticisms formulated by some commentators of the absence in the European Social Dialogue of a direct link or interaction with enterprise-level representatives. Bercusson, in particular, argues that 'given the existing links with Member States trade unions, it would strengthen the legitimacy of EU level trade union organizations if trade union rights formulated at EU level reinforced trade union representation over enterprise or workplace-based representation'. ${ }^{271}$ In this respect Bercusson emphasizes the importance of the creation of the EWCs, which 'promote for the first time "a trans-national system of worker representation based on the enterprise" '.272

The High Level Group Report also helps to resolve the problems of representing and protecting the interests and rights of those workers who are not members of any trade union and of those who may be affected by actions to

\footnotetext{
267 The High Level Group defines it as 'the way society organises and rules itself in order to make and to implement choices'. See High Level Group Report, above n. 259, 25 and 34.

268 Ibid., 24-5. 269 Ibid., 33. 270 Ibid., 36. 271 See Bercusson, above n. 146, 99.

272 Ibid. See also Barnard, above n. 167, 83, for whom the European Works Council Directive, $94 / 95 / \mathrm{EC}$, poses the conditions for 'a space for local experimentation and adaptation by enterpriselevel social partners'.
} 
promote social inclusion, which is not generally covered by traditional collective agreements. ${ }^{273}$ The Report in fact gives a broad notion of industrial relations, covering 'not only the relations between workers and management or between the organizations representing them, and involving not only regulation of wages and employment conditions, but also the relevant legal and institutional frameworks and public policies'. ${ }^{274}$ The insertion of public policies, in particular, is very significant as it highlights the development of an overall EU social policy agenda. ${ }^{275}$ In this context, Working Group XI on Social Europe of the European Convention maintains that the role of the social partners should be recognized explicitly in Title VI of the Constitutional Treaty on democracy of the European Union. ${ }^{276}$

Moreover, a new Communication was issued in June 2002 to strengthen and enhance the European Social Dialogue. ${ }^{277}$ This confirms and further develops the Report of the High Level Group on 'Industrial Relations and change in the European Union'. It considers 'social dialogue as a key to better governance of the enlarged Union and as a driving force for economic and social reform'. ${ }^{278}$ The Communication promotes the development of an 'autonomous social dialogue'279 in line with the European social partners' Laeken declaration ${ }^{280}$ and supported by the Spring European Council in Barcelona. ${ }^{281}$ Apart from the establishment of joint work programmes and the submission of an annual report on their contributions, the Commission proposes to set up a new 'tripartite social summit' in the context of the Lisbon strategy. ${ }^{282}$ But probably the most important innovation is the proposal to strengthen the social partners' involvement in the open method of co-ordination, 'including consultation of the social partners prior to the drafting of the proposal for employment guidelines and encouraging greater use of the technical assistance available for the social partners to enable them to report back on the implementation

273 Ibid., 92; see also Bernard, above n. 7, 288.

274 See High Level Group Report, above n. 259, $9 . \quad 275$ See Kenner, above n. 32, chap. 11.

276 See European Convention, Final Report of Working Group XI on Social Europe, Brussels, 30 Jan. 2003, CONV 516/03, WG XI 9, Part VII.

277 See Communication from the Commission, 'The European social dialogue, a force for innovation and change. Proposal for a Council Decision establishing a Tripartite Social Summit for Growth and Employment', COM(2002)341 final. 278 See COM(2002)341 final, 4 and 6.

279 See Framework Agreement on Telework of 16 July 2002, available online at: www.eiro.eurofound.ie/2002/07/feature/EU0207204F.html. It will be the first European Agreement to be implemented directly by the social partners themselves rather than by a decision of the Council. The agreement will be applied within 3 years of its signature. The member organizations of the signatories will report on the implementation of the agreement to an ad hoc group set up by the signatories. This group will then prepare a joint report on implementation within 4 years after the signature of the agreement.

280 For information on the content of the social partners' Laeken Declaration of 14-15 Dec. 2001, see website, available online at: www.eiro.eurofound.ie/2001/12/feature/EU0112262F.html. 281 Ibid.

282 Ibid., 4 and 14. This will replace the Standing Committee, which is the mechanism through which the Council, the Commission, and employers' and employees' organizations consult each other and discuss the Employment Strategy, and represented a permanent forum for consultation of the social partners and discussion on the Luxembourg Process in the framework of the EPGs and the BEPGs. 
of the employment guidelines'. ${ }^{283}$ Thus the Communication clearly aims at creating a link between the objectives of Titles VIII and XI. The Communication also highlights the unique position of the social partners within civil society 'because they are best-placed to address issues related to work and can negotiate agreements, which include commitments' and the importance of strengthening participatory forms of democracy by emphasizing the importance of involving all actors in decision-making. ${ }^{284}$ The Commission sets out ways in which to improve the European social dialogue. It does so by suggesting the setting up of an 'interdepartmental working party' and the drafting of an 'internal code of conduct' on consultation with the social partners. ${ }^{285}$ Finally, with regard to the representativeness of the social partners the Commission partially confirms the criteria laid down in its previous Communications by limiting their application to the consultation stage. ${ }^{286}$ However, it states that it will carry out studies on representativeness 'to cover further sectors reflecting developments in the European economy and prepare studies on the intersectoral and sectoral social partner organizations in the candidate countries and that it will present an amended list of organizations consulted under Article $138 \mathrm{EC}$. It will adjust the list again if necessary if new social dialogue committees are set up and in the light of the results of the study on representativeness.'. ${ }^{287}$

\section{Effective Judicial Protection of Social Rights}

Ekengren and Jacobsson argue that it is necessary to establish a judicial framework able to regulate and balance the fundamental competence claims of the Union and the Member States that are the result of EU co-operation in policies pertaining to employment'. ${ }^{288}$

Sciarra suggests the creation of new bodies, similar to the European Social Charter's Committee of Independent Experts. ${ }^{289}$ In this respect the Treaty of Nice provides that the Council can set up specialized chambers to examine at first instance certain categories of actions in specific matters and that an appeal in cassation can be brought before the CFI against a decision by specialized chambers. ${ }^{290}$ She suggests not duplicating procedures but making them converge towards institutional co-operation. In practice the new body

283 For information on the content of the social partners' Laeken Declaration of 14-15 Dec. 2001, see website, available online at: www.eiro.eurofound ie/2001/12/feature/EU0112262Fhtml. See also $14-15$ and $17-18$.

285 Ibid., $9 . \quad 286$ See COM(93)600 final and COM(98)322 final.

287 See COM(2002)341 final, 9 and 16-17.

288 See M. Ekengren and K. Jacobsson, 'Explaining the Constitutionalisation of EU Governancethe Case of European Employment Co-operation' 15, available online at: www.score.su.se/pdfs/ 2000-8.pdf. For a similar view see also Sciarra, above n. 232, 169.

289 See Sciarra, above n. 118, 499.

290 See amended Art. 220(2) EC: 'In addition, judicial panels may be attached to the Court of First Instance under the conditions laid down in Article 225a in order to exercise, in certain specific areas, the judicial competence laid down in this Treaty' and new Art. 225a EC. See Treaty of Nice, amending the TEU, the Treaties establishing the European Communities, and certain related Acts, SN 1247/01, 42. 
should have both monitoring powers and powers to refer to the Commission when infringements of social rights are discovered. It should be built into the Community legal order and include representatives from other international organizations, such as the Council of Europe and the ILO, thus enhancing convergence of international standards. ${ }^{291}$ Sciarra adds that this monitoring mechanism could in exceptional circumstances lead to sanctions applied to Member States that fail to respect fundamental social rights. ${ }^{292}$

Following Sciarra's proposals my main contention is that, added to a new committee, the social partners at the national, sectoral, and enterprise levels and work councils could monitor the protection of social rights and report any complaints to their representatives at the European level, who could bring actions before the European Courts. An alternative solution, which would not require the creation of a new institution, could be for the European Court to revisit its case law on Article 230 EC. ${ }^{293}$

To date, the Court has limited the circumstances in which a non-privileged litigant can challenge the EU institutions. ${ }^{294}$ The conditions created by the Court of Justice in fact to satisfy the requirements of 'individually and directly concerned' are such that individual plaintiffs or groups representing individuals are for the most part restrained from challenging directly Community measures. The restrictive approach to the rules regulating access of individuals and group standing has been subject to strong criticism. ${ }^{295}$ A very significant change to the quality of the jurisdiction of the Court would be, therefore, to allow citizens and, by inference, non-governmental associations and the social partners to seek judicial review directly. Not only would this consolidate human rights protection at the EU level, but it would also increase the means of redress available at the national level. More specifically, trade associations and works councils could introduce collective complaints when social rights are infringed by Member States, as well as when insufficient action is taken. In this context, Szyszczak suggests that a solution for recognizing the emergent legal interests could be 'by way of drawing parallels with the rise of third party

291 See Sciarra, above n. 118, $499 . \quad 292$ Ibid.

293 Art. 230(4) EC provides that: 'Any natural or legal person may, under the same conditions, institute proceedings against a decision addressed to that person or against a decision, which, although in the form of a regulation or a decision addressed to another person, is of direct and individual concern to the former'. Cf. Art. 230(4) EC with the provisions of Arts. 33-36 ECSC, which made it easier for citizens to challenge directly ECSC Institution measures. On 23 July 2002 the ECSC ceased to exist as its Treaty expired.

294 A. Arnull, 'Private Applicants and the Action for Annulment under Article 173 of the EC Treaty' (1995) 32 CML Rev. 7; A. Arnull, 'Private Applicants and the Action for Annulment since Codorníu' (2001) 38 CML Rev. 7.

295 For recent criticism by commentators, see Arnull, 'Private Applicants and the Action for Annulment since Codorníu', above n. 294, 7; P. Alston and J. Weiler, “'An Ever Closer Union” in Need of a Human Rights Policy: The European Union and Human Rights' in Alston, Bustelo, and Heenan, above n. 118, 52-4; C. Harlow, 'Access to Justice as a Human Right: The European Convention and the European Union' in Alston, Bustelo, and Heenan, above n. 118, 192-200; B. de Witte, 'The Past and Future Role of the European Court of Justice in the Protection of Human Rights' in Alston, Bustelo, and Heenan, above n. 118, 875-7. 
claims and recognition of limited rights, especially those of competitors, in the competition sphere where the Court of Justice has showed a willingness to protect certain kinds of economic interests'. ${ }^{296}$

However, it was not until the recent judgment delivered by the Court of First Instance (CFI) in the Jégo-Quéré case ${ }^{297}$ that a less restrictive approach to the rules of access of non-privileged litigants was applied. The CFI has taken a more liberal approach to the concept of 'individual concern', 298 and it draws inspiration from the Opinion of Advocate General Jacobs in the UPA case. ${ }^{299}$ First, the CFI found that the option of indirectly challenging a Community measures by way of having recourse to Article 234 EC is not always available to individuals. ${ }^{300}$ National rules of standing may in fact defeat meritorious plaintiffs without the case ever reaching the European Court. ${ }^{301}$ And national courts may also decide not to make a preliminary reference. Secondly the CFI found that the possibility of claiming damages against the Community under Articles 235 and 288 EC does not provide a solution that 'satisfactorily protects

296 See E. Szyszczak, 'Social Policy in the Post-Nice Era' in A. Arnull and D. Wincott (eds.), Accountability and Legitimacy in the European Union (OUP, Oxford, 2002); see Case C-152/88 Sofrimport [1990] ECR I-2477; Case C-309/89 Codorníu v. Council [1994] ECR I-1853; Cases $\mathrm{T}-3 / 93$ \& $\mathrm{T}-2 / 93$ Société Anonyme et Participation Ouvrière Cie Nationale Air France $v$. Commission [1994] ECR II-121; Case T-435/93 Aspec v. Commission, judgment of 27 Apr. 1995; Case T-96/92 Comité Central d'Entreprise de la Société Générale des Grandes Sources and others $v$. Commission [1995] ECR II-1213; Case T-12/93 Comité Central d'Entreprise de la Société Anonyme Vittel and others v. Commission [1995] ECR II-1247; Case T-189/97 Comité Central de la Société Française de Production and others $v$. Commission [1998] ECR II-335.

297 Case T-177/01 Jégo-Quéré et Cie SA v. Commission, judgment of 3 May 2002, available online at: www.curia.eu.int.

298 The CFI stated that 'A natural or legal person is to be regarded as individually concerned by a Community measure of general application that concerns him directly if the measure in question affects his legal position, in a manner which is both definite and immediate, by restricting his rights or by imposing an obligation on him'. See Case T-177/01 Jégo-Quéré et Cie SA $v$. Commission, judgment of 3 May 2002, available online at: www.curia.eu.int, para. 51. The definition given by Jacobs AG is different. A private applicant should be individually concerned 'where, by reasons of his particular circumstances, the measure has, or is likely to have, a substantial adverse effect on his interest'. Cf. Case C-25/62 Plaumann v. Commission [1963] ECR 95 and Case C-451/98 Antillean Rice Mills, judgment of 22 Nov. 2001, available online at: www.curia.eu.int, para. 49 .

299 See Opinion of Jacobs AG in Case C-50/00 P, Unión de Puequeños Agricultores $v$. Council of the European Union, on 21 Mar. 2002, available online at URL: http://www.curia.eu.int, paras. 33-35, 36-44, 45-49, and 59-99. In contrast to the CFI ruling given in the case and to Jacobs AG's proposal to change its jurisprudence, the European Court, however, has reaffirmed its case law and rejected the action for annulment of UPA. See Case C-50/00 P, Unión de Puequeños Agricultores $v$. Council of the European Union, judgment of 25 July 2002. For support for wider access for individual applicants in other Opinions of AGs see: Opinion of Slynn AG in Case 246/81 Bethell [1982] ECR 2277, 2299; Opinions of Jacobs AG in Case C-358/89 Extramet Industrie [1991] ECR I-2501, paras. 71-74 and in Case C-188/92 TWD Textilwerke Deggendorf [1994] ECR I-833, paras. 20-23; Opinion of Ruiz-Jarabo Colomer AG in Case C-142/95 P Associazione Agricoltori della Provincia di Rovigo and others [1996] ECR I-6669, paras. 40-41.

300 See Case T-177/01, para. 45. See Case C-321/95 Stichting Greenpeace Council (Greenpeace International) v. Commission [1998] ECR I-1651, where the ECJ said that individuals may always seek a remedy before national courts which may, or in prescribed circumstances must, make reference to the ECJ under Art. 177 (now Art. 234) EC.

301 Alston and Weiler, above n. 295, 53. 
the interests of the individual affected' 302 because of the intrinsic difference in nature, purposes, and consequences between the action for annulment and the action for damages. The CFI thus concluded that 'the procedures provided for in, on the one hand, Article $234 \mathrm{EC}$ and, on the other hand, $235 \mathrm{EC}$ and the second paragraph of Article 288 EC can no longer be regarded, in the light of Articles 6 and 13 ECHR and of Article 47 of the Charter of Fundamental Rights, as guaranteeing persons the right to an effective remedy enabling them to contest the legality of Community measures of general application which directly affect their legal situation'. ${ }^{303}$

The ruling in the Jégo-Quéré case is extremely important; however, the new interpretation of 'individual concern' is not per se of great benefit to the protection of collective rights and more particularly to trade unions, works councils, and public interests groups.

Problems in fact still remain with regard to the term 'direct concern' in Article 230(4) EC. Direct concern normally requires the existence of a causal link between the act and the effects on the applicant. Two factors are taken into consideration: whether there has been the intervention of a discretionary power and the nature of the effect of a given measure on the plaintiff. In one of the Nestlé/Perrier cases ${ }^{304}$ the CFI stated that bodies representing employees concerned about social consequences of concentration of various companies authorized by a Commission's decision were not directly concerned by that decision because 'only a decision which may have an effect on the status of the employees' representative organizations or on the exercise of the prerogatives and duties given to them by the legislation can affect such organizations' own interest'. ${ }^{305}$

The Jégo-Quéré ruling may favour the access of group applicants; however, the requirement of direct effect may be problematic if the latter cannot show that their rights ${ }^{306}$ have not been affected by a Community measure. In fact since the interests protected by such associations, i.e., of those whom they represent, are not relevant to determine whether there is 'direct concern' these non-privileged parties would not stand the direct concern test. ${ }^{307}$ The joint reading of Articles 12, 27, 28, and 47 of the EU Charter of Fundamental Rights in tandem with Articles 6 and 13 of the ECHR could be used to argue for a new and more liberal interpretation of 'direct concern' and could, therefore, guarantee the wider access of trade associations and work councils to the Community Courts.

\footnotetext{
302 See Case T-177/01, Jégo-Quéré et Cie SA v. Commission, judgment of 3 May 2002, available online at: www.curia.eu.int, para. 46. 303 Ibid., para. 47

304 See Case T-96/92 Comité Central d'Entreprise de la Société Générale des Grandes Sources and others v. Commission [1995] ECR II-1213.

305 See ibid., para. 38. See also Case T-12/93 Comité Central d'Entreprise de la Société Anonyme Vittel and others $v$. Commission [1995] ECR II-1247; Case T-189/97 Comité Central de la Société Française de Production and others $v$. Commission [1998] ECR II-335. For further analysis of this case law see Arnull, above n. 294, 25-30. 306 i.e., procedural rights.

307 See Case C-321/95 Stichting Greenpeace Council (Greenpeace International) v. Commission [1998] ECR I-1651.
} 
Finally, the Treaty of Nice, ${ }^{308}$ which introduces more flexibility in the processing and allocation of cases, ${ }^{309}$ and the further amendments of the Community Court's Rules of Procedures, ${ }^{310}$ which include the accelerated treatment of cases, provide the European Courts with further effective means to face the excessive volume of applications in view of the enlargement process. These amendments could also foster a less restrictive approach to Article 230(4) EC.

\section{Conclusion}

In this chapter I showed how the political discourse on EU governance has now definitely reached the top of the agenda of the European Union. The analysis undertaken so far shows that the evolution of EU governance in the field of social policy raises crucial constitutional questions. The new transnational and multi-tiered modes of governance in fact lack institutional fora through which the main actors in civil society may develop forms of representative participation. New sources of law are created with different and often uncertain legal effects, particularly with respect to the acquis communautaire. Moreover, the EU system does not provide effective legal remedies to protect the new rights to consultation and involvement in the decisionmaking system. Hence most commentators, including the European institutions, agree on the need to introduce some changes in order to overcome the Community's structural inadequacy and legislative sclerosis to confront the new regulatory problems. The study has also revealed that there are mainly two schools of thought. Some scholars argue that the amendments to the EC Treaty should focus mainly on the extant institutional design by strengthening the EU Community method and the European Social Dialogue; another school of thought, on the contrary, focuses on the emergence of the new trans-national political actors and on a functional representation of the citizens and calls for the introduction of participatory or associative democracy by structuring group-based interest associations within the EU decision-making process. ${ }^{311}$

\footnotetext{
308 The CFI becomes the common law judge for all direct actions, particularly proceedings against a decision (Art. $230 \mathrm{EC}$ ), action for failure to act (Art. $232 \mathrm{EC}$ ), action for damages (Art. 235 EC), with the exception of those which will be allocated to a specialized chamber and those the statute reserves for the Court itself. See amended Art. 225 EC. See the Treaty of Nice, amending the TEU, the Treaties establishing the European Communities, and certain related Acts, SN 1247/01, 45-6. The ECJ retains responsibility for other proceedings, particularly actions for failure to fulfil obligations (Art. $226 \mathrm{EC}$ ), but the statute can entrust to the CFI categories of proceedings other than those listed in Art. 225 EC. The idea is to maintain within the Court, as the jurisdictional supreme body of the EU, disputes concerning essential Community issues. See new Art. 229a EC and amended Art. 230 EC. See Treaty of Nice, amending the TEU, the Treaties establishing the European Communities, and certain related Acts, SN 1247/01, 48-9.

309 See also ECJ and CFI, 'The Future of the Judicial System of the European Union, Proposals and Reflections', available online at: curia.eu.int/en/txts/intergov/ave.pdf.

310 See amended CFI Rules of Procedure [2000] OJ L322/1 and ECJ Rules of Procedure [2000] OJ L122/43.

311 i.e., representation based on social and economic lines rather than territoriality. Art. I-46 of the Constitutional Treaty, above n. 216.
} 
I thus suggested a series of amendments to Titles VIII and XI of the EC Treaty, which aim to improve the effectiveness of the EU decision-making system ${ }^{312}$ by way of combining these two schools of thought.

Finally, I showed how there is reciprocal influence between the EES and EC labour law and between the European Court's case law and the EU Charter of Fundamental Rights.

The proposals made are in line with the processes of consolidation taking place in EC labour law and constitutionalization enacted by the European Court of Justice.

312 For a meaning of effectiveness see F. Snyder, 'The Effectiveness of European Community Law: Institutions, Processes, Tools and Techniques' (1993) 56 MLR 25-6. 
EECK-CH09.qxd 2/19/04 2:59 PM Page 406 